\title{
Aglaopheniid hydroids (Cnidaria: Hydrozoa: Aglaopheniidae) from off New Caledonia collected during KANACONO and KANADEEP expeditions of the French Tropical Deep-Sea Benthos Program
}

\author{
Horia R. GALEA \\ Hydrozoan Research Laboratory, 405 Chemin Les Gatiers, 83170 Tourves, France. \\ Email: horia.galea@gmail.com \\ urn:1sid:zoobank.org:author:DE5AC672-0243-46F2-A910-AFF4E91A4C5D
}

\begin{abstract}
Sixteen aglaopheniid hydroids occurring in two recent, deep water collections from off New Caledonia are reported upon, of which 8 species are new, namely Cladocarpus asymmetricus sp. nov., C. partitus sp. nov., C. pennatus sp. nov., Lytocarpia fragilis sp. nov., L. pilosa sp. nov., L. pseudoctenata sp. nov., L. subtilis sp. nov. and Macrorhynchia spiralis sp. nov., the latter producing medusoid gonophores. Although not occurring in the present collections, brief notes on M. disjuncta (Pictet, 1893), including the first description of its gonosome, are provided to support its specific separation from M. phoenicea (Busk, 1852).
\end{abstract}

Keywords. Deep water, Leptothecata, taxonomy, new species.

Galea H.R. 2020. Aglaopheniid hydroids (Cnidaria: Hydrozoa: Aglaopheniidae) from off New Caledonia collected during KANACONO and KANADEEP expeditions of the French Tropical Deep-Sea Benthos Program. European Journal of Taxonomy 615: 1-47. https://doi.org/10.5852/ejt.2020.615

\section{Introduction}

This is the second report of a developing series dealing with the hydroids collected during the KANACONO (2016) and KANADEEP (2017) expeditions of the French Tropical Deep-Sea Benthos Program.

The first report (Galea \& Schuchert 2019) dealt with hydroids belonging to various families, viz. Staurothecidae Maronna et al., 2016, Syntheciidae Marktanner-Turneretscher, 1890, Sertulariidae Lamouroux, 1812, Sertularellidae Maronna et al., 2016, Symplectoscyphidae Maronna et al., 2016, Thyroscyphidae Stechow, 1920 and Zygophylacidae Quelch, 1885.

The present report focuses on the family Aglaopheniidae Marktanner-Turneretscher, 1890, which provided 16 species assignable to the genera Aglaophenia Lamouroux, 1812 (two species), Cladocarpus Allman, 1874 (four species, of which one is new), Gymnangium Hincks, 1874 (one species), Lytocarpia Kirchenpauer, 1872 (seven species, of which four are new) and Macrorhynchia Kirchenpauer, 1872 (two species, one of which is new). Brief notes on the hydroid Macrorhynchia disjuncta (Pictet, 1893), 
not occurring in the present material, are provided in order to support its specific separation from M. phoenicea (Busk, 1852), a species present in both collections.

\title{
Material and methods
}

Study methods were described in Galea $(2007,2008)$. Station numbers, as indicated in the text, are preceded by a two-letter prefix referring to the sampling gear used to secure the material, either a beam trawl (CP), a rocky bottom dredge (DR) or a Warrén dredge (DW). The material, fixed and preserved in ethanol, is deposited in the collections of Muséum national d'histoire naturelle (MNHN) of Paris, France, and catalogue numbers are indicated as MNHN-IK-2015- followed by 3-digit numbers.

\section{Results}

\section{Systematic account}

\author{
Class Hydrozoa Owen, 1843 \\ Subclass Hydroidolina Collins, 2000 \\ Order Leptothecata Cornelius, 1992 \\ Family Aglaopheniidae Marktanner-Turneretscher, 1890 \\ Genus Aglaophenia Lamouroux, 1812 \\ Aglaophenia howensis Briggs, 1918 \\ Figs $1 \mathrm{~A}-\mathrm{B}, 2$
}

Halicornaria sp. nov. Whitelegge, 1899a: 41.

Aglaophenia howensis Briggs, 1918: 27, pl. 5 figs 1-2, pl. 6 fig. 1.

Lytocarpia howensis - Vervoort \& Watson 2003: 311, fig. 75a-d.

\section{Material examined}

PACIFIC OCEAN -3 plumes without hydrorhizae, $5 \mathrm{~cm}, 10 \mathrm{~cm}$ and $10 \mathrm{~cm}$, respectively, the latter bearing gonothecae; off New Caledonia, stn CP4786; 22 ${ }^{\circ} 46^{\prime} \mathrm{S}, 167^{\circ} 42^{\prime} \mathrm{E}$; 350-469 m; 29 Aug. 2016; KANACONO leg.; MNHN-IK-2015-544.

\section{Remarks}

For a thorough description of this species, refer to Briggs (1918). Vervoort \& Watson (2003) removed it from Aglaophenia Lamouroux, 1816 and placed it in Lytocarpia Kirchenpauer, 1872, on the account of peculiarities of its hydrothecae, not taking into account the morphology of its gonosome, otherwise well documented in the original account. The species was then transferred back to Aglaophenia after the examination of the present material with corbulae, whose structure does not include hydrothecae at the base of the costae (Fig. 1B).

As noted by Briggs (1918), a reversal of the orientation of cladia, whose hydrothecae face either the frontal (F) or dorsal (D) aspect of the cormoid, could be noted. In the fertile plume available, this change occurs 12 times, as follows (from proximal to distal end): 15 (F), 10 (D), 7 (F), 12 (D), 19 (F), 10 (D), 8 (F), 13 (D), 34 (F), 26 (D), 29 (F), 32 (D), and 13 (F), the numbers representing the number of consecutive cladia per side of cormoid and per group of orientation. Implicitly, when corbulae are present within a given group, their orientation with respect to the side of the plume changes as well. 


\section{Distribution}

Scattered records from the Tasman Sea area, up to Norfolk Island in the North (Vervoort \& Watson 2003); New Caledonia (present report).

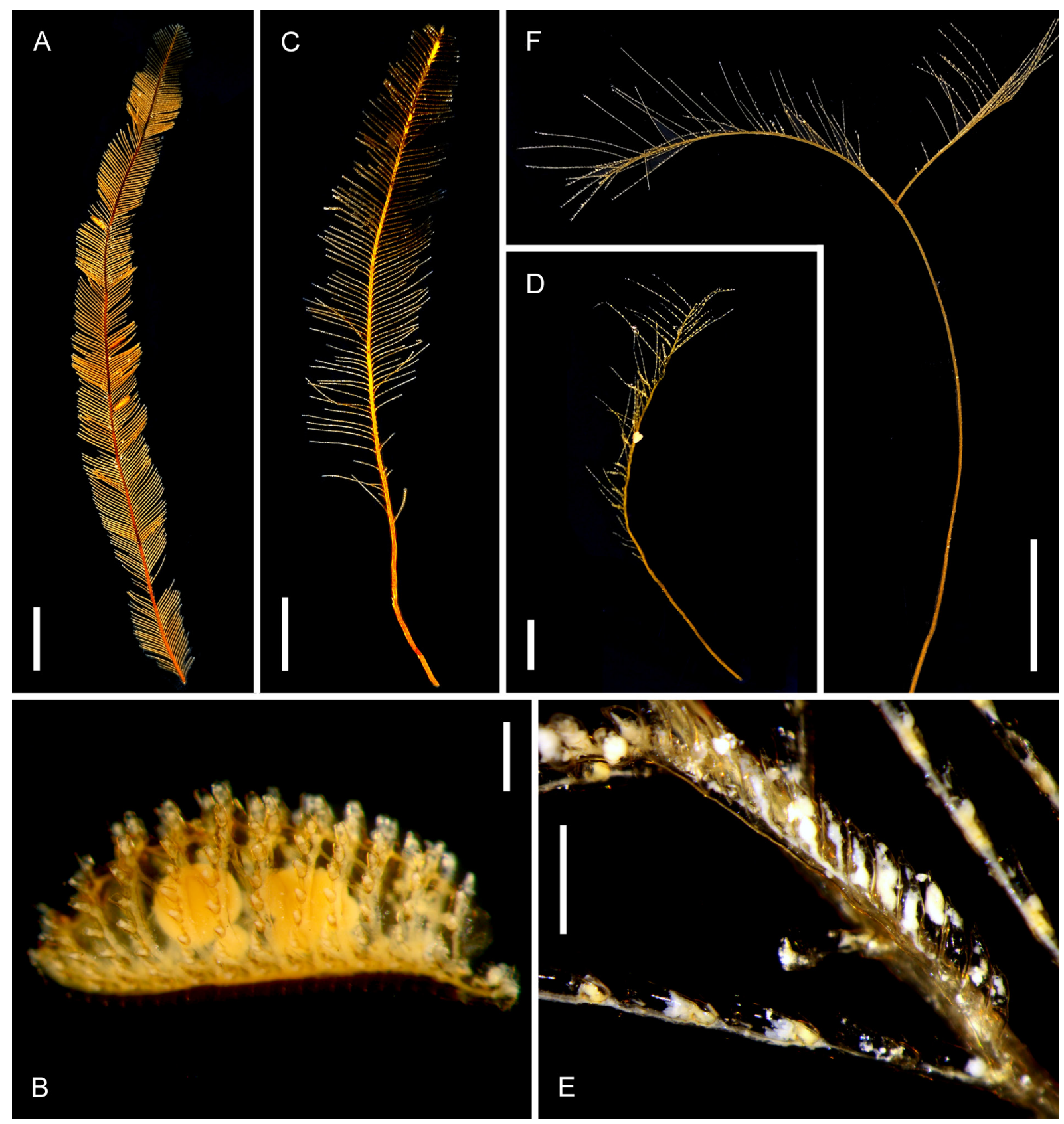

Fig. 1. A-B. Aglaophenia howensis Briggs, 1918, fertile cormoid (A) and corbula (B), both from sample MNHN-IK-2015-544. - C. Aglaophenia sinuosa Bale, 1888, cormoid from sample MNHNIK-2015-545. - D-E. Cladocarpus asymmetricus sp. nov., fertile cormoid (D) and phylactocarp (E) from sample MNHN-IK-2015-530 (holotype). - F. Cladocarpus keiensis Schuchert, 2003, colony from sample MNHN-IK-2015-534. Scale bars: $F=2 \mathrm{~cm} ; A, C-D=1 \mathrm{~cm} ; E=1 \mathrm{~mm} ; \mathrm{B}=500 \mu \mathrm{m}$. 

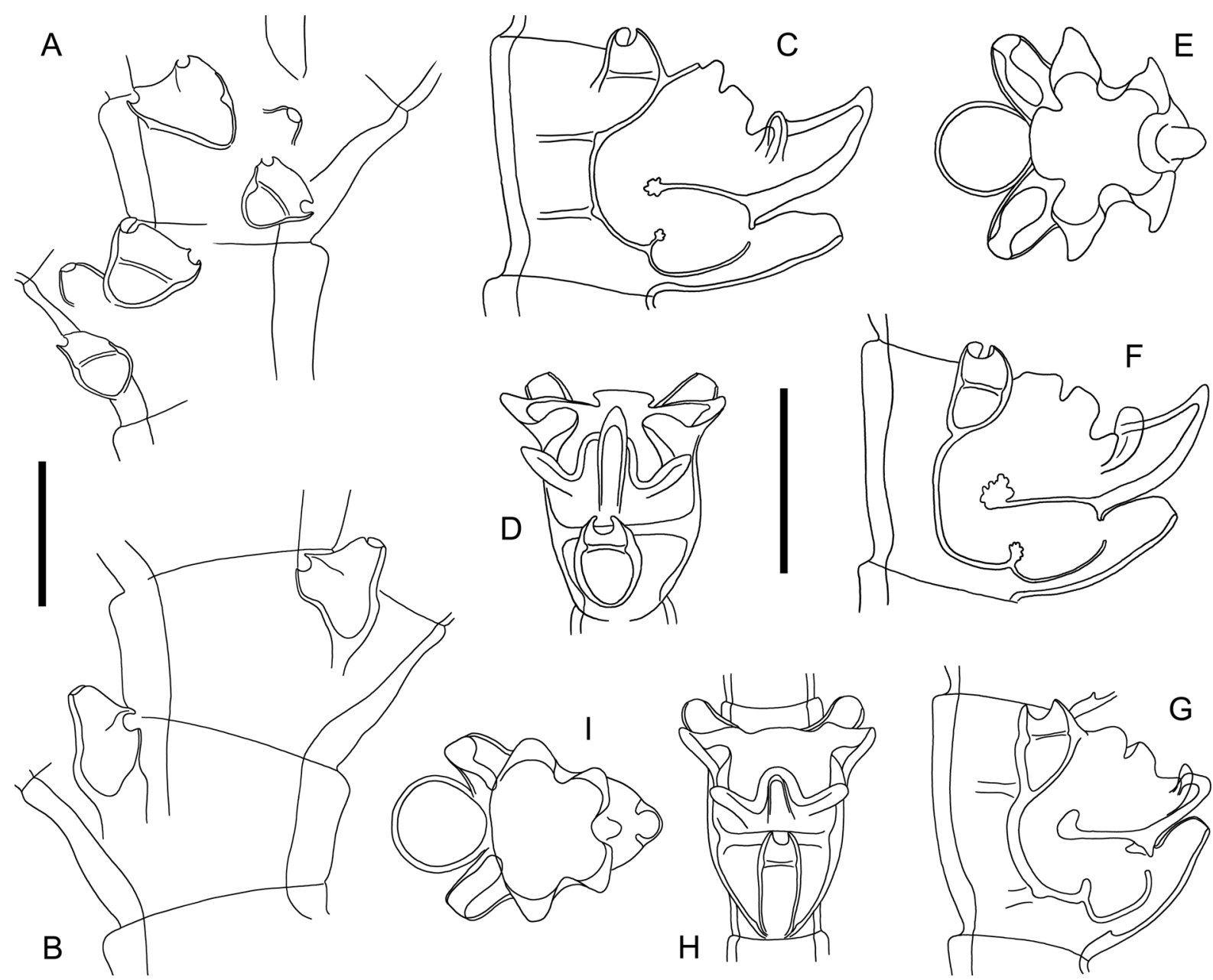

Fig. 2. Aglaophenia howensis Briggs, 1918, from sample MNHN-IK-2015-544. A-B. Portion of a stem in frontal aspect (A) and of another stem in dorsal aspect (B). C-F. Two hydrothecae from one colony in lateral (C, F), frontal (D) and apical (E) views. G-I. A hydrotheca from another colony in lateral (G), frontal $(\mathrm{H})$ and apical (I) aspects. Scale bars: $\mathrm{A}-\mathrm{H}=200 \mu \mathrm{m}$.

\section{Agalophenia sinuosa Bale, 1888}

Figs $1 \mathrm{C}, 3$

Aglaophenia sinuosa Bale, 1888: 790, pl. 21 figs 1-2.

Aglaophenia bakeri Bale, 1919: 353, pl. 17 figs 7-8.

Aglaophenia sinuosa - Whitelegge 1889b: 194. — Jäderholm 1917: 19, pl. 2 fig. 9. — Bale 1919: 352. — Watson 1994: 67; 2002: 347, fig. 6e-h; 2018: 19, fig. 8b-f. — Vervoort \& Watson 2003: 278, figs $65 \mathrm{e}-\mathrm{f}, 66 \mathrm{a}-\mathrm{e}$.

Aglaophenia bakeri-Watson 1994: 67; 2018: 19.

\section{Material examined}

PACIFIC OCEAN 1 plume, ca $8.5 \mathrm{~cm}$ high, hydrorhiza and gonothecae missing; off New Caledonia, stn DW4970; $21^{\circ} 01^{\prime} \mathrm{S}, 158^{\circ} 31^{\prime}$ E; 750 m; 8 Sep. 2017; KANADEEP leg.; MNHN-IK-2015-545. 


\section{Remarks}

For modern descriptions of this species, refer to Watson $(2002,2018)$ and Vervoort \& Watson (2003).

As noted by Watson (2002), A. sinuosa is easily recognizable through the sinuous bends at intervals along the stem that mark a reversal of the orientation of cladia. Although a reversal is present in sample MNHN-IK-2015-545, the condition of the stem is little affected.

\section{Distribution}

South and SE Australia, Tasman Sea (Watson 2018), New Caledonia (present study).
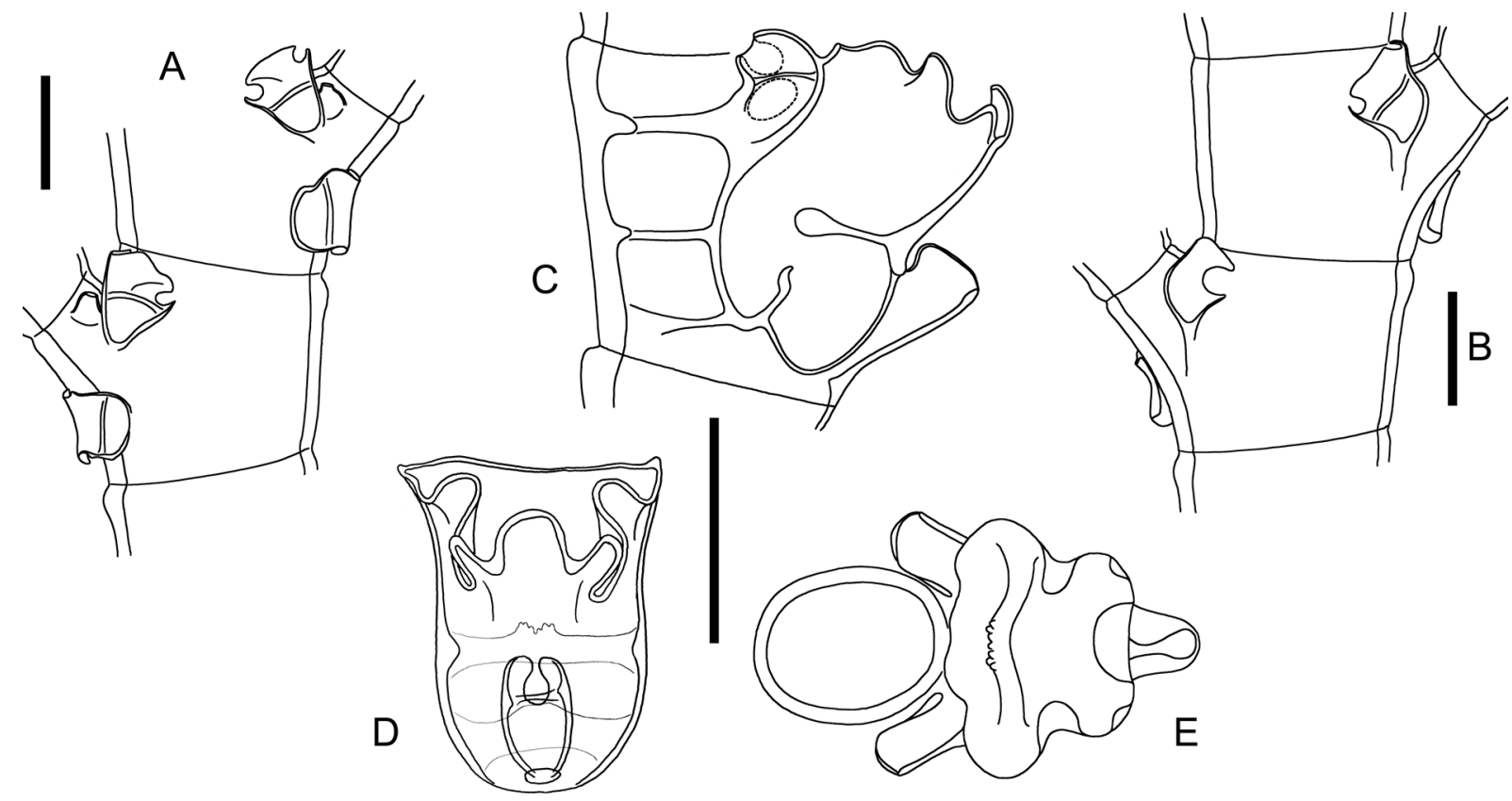

Fig. 3. Aglaophenia sinuosa Bale, 1888, from sample MNHN-IK-2015-545. A-B. Same portion of a stem in frontal (A) and dorsal (B) aspects. C-E. Same hydrotheca in lateral (C), frontal (D) and apical (E) views. Scale bars: A-E $=200 \mu \mathrm{m}$.

\section{Genus Cladocarpus Allman, 1874}

Cladocarpus asymmetricus sp. nov. urn:1sid:zoobank.org:act:765A957F-FEF6-47A6-B09A-314F31F0440E

Figs 1D-E, 4; Table 1

\section{Diagnosis}

Cladocarpus with lightly fascicled, unbranched stems divided into fairly long internodes, each with 2-3 frontal nematothecae, a mamelon and an axillar nematotheca. Cladia close to one another. Cormidia with up to 7 intranodal, adaxial septa. Hydrothecae elongated, asymmetrical in frontal view, with two lateral transverse ridges projecting into the lumen, rim with 9 rounded cusps. Phylactocarps given off from first cormidium, gonothecae concrescent with the rachis basally, crescent-shaped, with three types of nematothecae on both body and apex. 


\section{Etymology}

From the Latin 'ăsymmĕtěr, -tra, -trum', meaning 'asymmetrical', with reference to the shape of the hydrotheca in frontal view.

\section{Material examined}

\section{Holotype}

PACIFIC OCEAN $\bullet 1$ single plume, ca $8.5 \mathrm{~cm}$ high, hydrorhiza missing; off New Caledonia, stn DW4979; $19^{\circ} 42^{\prime}$ S, $158^{\circ} 37^{\prime}$ E; 315-295 m; 9 Sep. 2017; KANADEEP leg.; MNHN-IK-2015-530.

\section{Description}

Colony erect, at least $8.5 \mathrm{~cm}$ high, hydrorhiza missing. Stem unbranched, fairly fascicled, accessory tubes forming a beam around the main tube; no deeply-cut, proximal, oblique nodes; elsewhere division into internodes indistinct, except for distalmost, monosiphonic part, with thinner perisarc, where transverse nodes $(165-180 \mu \mathrm{m}$ wide) delimit rather long $(820-1030 \mu \mathrm{m})$ internodes composed of 2-3 (occasionally 4) proximal nematothecae in a row, a lateral cladial apophysis with its associated conical nematotheca (with rounded, apical aperture), and an axillar nematotheca rather lateral to the apophysis; dorsal axillar nematotheca absent; all stem nematothecae sac-shaped, adnate for $2 / 3$ of their length, with apical, guttershaped aperture facing adaxially; each accessory tube of the stem with a row of saccate, deeply immersed nematothecae, with only their ovoid apertures slightly protruding from the perisarc. Cladial apophyses alternate along the stem, ending distally in a deeply oblique node; cladia close to one another, up to $1.9 \mathrm{~cm}$ long, divided into rather long internodes $(1025-1090 \mu \mathrm{m})$ by means of slight, transverse (115$120 \mu \mathrm{m}$ wide) constrictions of the perisarc, each accommodating a hydrotheca and its 3 nematothecae: one mesial and a pair of laterals flanking the aperture. Hydrotheca elongated, 895-950 $\mu \mathrm{m}$ deep, slightly compressed laterally below the rim, with straight adaxial and slightly curved abaxial walls, with an intrathecal septum given off from the lower $1 / 4$ of the adaxial wall, and projecting for a short distance into the lumen; in frontal view, lower part of hydrotheca asymmetrical, due to the presence of two conspicuous, semicircular, intrathecal plates given off at two different levels from the lateral walls; free edges slightly overlapping in the middle of the lumen; in a lateral view of the hydrotheca, the attachment sites of these septa are distinctly sigmoid. Mesial nematotheca long, tubular, adnate for about $3 / 4$ its length, leaving distally a short $(90-95 \mu \mathrm{m})$, gutter-shaped aperture; lateral nematothecae short (195-200 $\mu \mathrm{m})$, tubular, tapering towards the distal aperture, the latter with deeply scooped margin on adaxial side. Hydrothecal aperture 300-305 $\mu \mathrm{m}$ wide, rim with 9 cusps: one median, abaxial with squared outline, and 4 pairs of laterals, the latter triangular in shape, with rounded tips, becoming gradually lower and wider towards the adaxial side of the theca; up to 7 intranodal septa, all given off from the adaxial wall of the hydrothecae and projecting for a relatively short distance into the lumen of the internode; of these, 2 cusps are given off from the adaxial thecal wall below the intrahydrothecal septum, while up to 5 others from above it. Phylactocarp given off laterally from first cormidium, borne on distinct, athecate apophysis with distal, oblique node; phylactocarp up to $6 \mathrm{~mm}$ long, composed of a slightly geniculate rachis divided into up to 20 short $(250-305 \mu \mathrm{m})$ internodes by means of slightly-marked, transverse nodes; each internode with a proximal nematotheca, a basally concrescent gonotheca, and a second nematotheca lateral to its insertion (both nematothecae elongated, with scooped rims adaxially); the proximalmost internode has an extra proximal nematotheca. Gonothecae crescent-shaped in lateral view, ca $850 \times 250 \mu \mathrm{m}$, those with curvature on one side alternating with those curved oppositely from the other side; circular in transverse section, tapering gently below and gradually above to form a pointed apex bearing a nematotheca with scooped rim; two dissimilar nematothecae, placed at nearly the same level on the adaxial side of the thecal wall, at about $1 / 3$ of the length above from the insertion of the gonotheca on the rachis: one nematotheca is conical, with thick walls and has a small, slightly scooped aperture, while the other is barrel-shaped, with thin walls and has a broad, circular aperture with entire 
margin; upper third of the adaxial gonothecal wall with 1 (occasionally 2) sac-shaped nematotheca(e) with scooped rim on adaxial side.

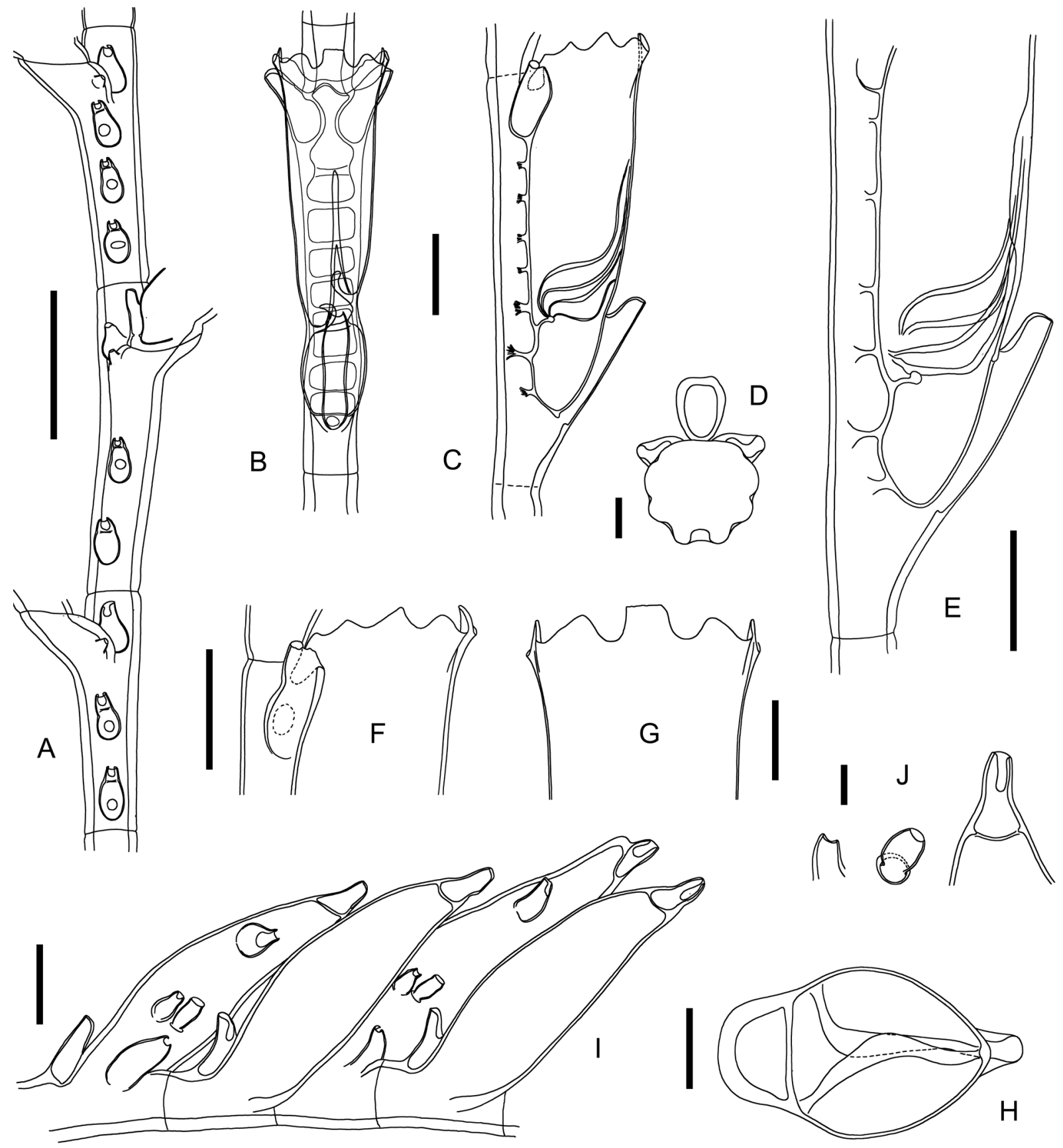

Fig. 4. Cladocarpus asymmetricus sp. nov., from sample MNHN-IK-2015-530. A. Portion of stem. B-H. Hydrotheca in frontal (B), lateral (C) and apical (D) views; details of its proximal (E) and distal (F) parts seen laterally, and of the rim in frontal view (G); intrathecal septum in an apical view of the hydrotheca (H). I-J. Portion of phylactocarp with gonothecae (I) and details of the nematothecae borne by the gonothecae (J). Scale bars: A $=500 \mu \mathrm{m}$; B-C, E-F, I $=200 \mu \mathrm{m} ; \mathrm{D}, \mathrm{G}-\mathrm{H}=100 \mu \mathrm{m} ; \mathrm{J}=50 \mu \mathrm{m}$. 
Table 1. Nominal species of Cladocarpus Allman, 1874 with (occasionally asymmetrical) hydrothecae provided with sigmoid (or nearly so) lateral ridges, similar to those of C. asymmetricus sp. nov., and their morphological differences with the new species.

\begin{tabular}{ll}
\hline Nominal species & $\begin{array}{l}\text { Brief description, with emphasis on the distinctive features, and geographical } \\
\text { distribution }\end{array}$
\end{tabular}

Colonies rather tall (up to $15 \mathrm{~cm}$ high), occasionally branched, fascicled; stem internodes with one frontal and a pair of axillar nematothecae, flanking the cladial apophyses, mamelon absent; cormidia with 7-8 intranodal septa, of which 2 are abaxial on proximal part; hydrothecae elongated, aperture slightly tilted forwards, margin with 11 rounded cusps, of which the median, abaxial one is the most Cladocarpus developed; mesial nematotheca adnate for a very short portion of the basal abaxial elongatus Bedot, wall of hydrotheca, laterals not overtopping the hydrothecal aperture; internal septum 1921 oblique rather than decidedly sigmoid, insertions on lateral walls of hydrotheca at different levels; phylactocarp borne on first cormidium, pinnate, branchlets with successive pairs of opposite to subopposite nematothecae; gonothecae ovoid, borne on apophyses of branchlets, male with apical, rounded, operculate aperture inclined to one side, female bigger, with broad, ovoid, lateral, subterminal aperture. Distribution: off the Atlantic coast of Morocco (Bedot 1921; Ramil et al. 1998).

Colonies rather tall (ca $12 \mathrm{~cm}$ high), with unbranched, fascicled stems; internodes with 1 frontal and a fronto-axillar nematotheca, apophyses alternate, without mamelons; cormidia with ca 7 intranodal septa, of which 3 are abaxial, below

Carpocladus

fertilis

Vervoort \&

Watson, 2003

Cladocarpus

sigma

(Allman, 1877)

Cladocarpus

unilateralis

Schuchert, 2015 the hydrotheca, the remaining 4 on adaxial side of the hydrotheca; abaxial wall with median carina, forming a conspicuous dagger-shaped projection on front of median marginal cusp; aperture slightly tilted forwards, rim with 4 pairs of lateral cusps; a strong adaxial ledge projecting into hydrothecal lumen, prolonged upwards sigmoidally on lateral walls; mesial nematotheca covering basal third of abaxial hydrothecal wall, laterals just over-reaching margin; phylactocarps borne on first cormidia, each internode with a gonotheca and a forked costa comprising a hydrotheca. Distribution: Tasman Sea (Vervoort \& Watson 2003).

Stems tall (ca $15 \mathrm{~cm}$ high), unbranched, fascicled (Allman 1877); internodes with 1 frontal nematotheca and 2 axillar nematothecae, conical nematotheca absent; cormidia with 5-7 intranodal septa; hydrotheca cup-shaped, with two lateral, intrathecal, sigmoidal ridges arising at different levels; margin with median abaxial cusps and 5 pairs of lateral cusps; mesial nematotheca short, barely surpassing hydrothecal base; lateral nematothecae short, not always reaching hydrothecal rim; phylactocarps pinnate, an ovate gonotheca at base of each costa (Bogle 1975). Distribution: tropical and subtropical western Atlantic (Vervoort 1972).

Colony tall (ca $40 \mathrm{~cm}$ high), stem loosely branched, fascicled, axis helical; cladia spirally arranged; hydrotheca longitudinally asymmetrical, with two "loopshaped ridges" on its lateral walls, not connecting ab- and adaxial walls; mesial nematotheca short, below the hydrothecal base; a lateral nematotheca on the cormidial internode; hydrothecal rim smooth, except for the median, abaxial cusp; lateral nematothecae exceedingly elongated, projecting frontally, almost reaching abaxial cusp. Distribution: Japan (Schuchert 2015). 


\section{Remarks}

The relationships between several related aglaopheniid genera, viz. Cladocarpus Allman, 1874, Aglaophenopsis Fewkes, 1881, Streptocaulus Allman, 1883 and Nematophorus Broch, 1918, have been discussed and interpreted by a number of authors (e.g., Ramil \& Vervoort 1992a; Ansín Agís et al. 2001; Altuna et al. 2013) on the account of morphological characters alone. To these should be added other genera, such as Carpocladus Vervoort \& Watson, 2003, Cladocarpoides Bogle, 1984 and Wanglaophenia Vervoort \& Watson, 2003, that make the case even more complex and, taken globally, it becomes evident that only a genetic study can be expected to clarify their relationships objectively.

The present hydroid, as well as Cladocarpus partitus sp. nov. and C. pennatus sp. nov. (see below), have gonosomes that do not conform accurately to any diagnosis of the abovementioned genera, displaying only some of their characters, as well as additional, distinctive ones. For this reason, these three new species are provisionally accommodated in the genus Cladocarpus, the oldest available name, pending a future phylogenetic study based on molecular markers.

A few congeners have hydrothecae resembling those of $C$. asymmetricus sp. nov., notably with respect to their elongated appearance and the presence of two lateral, oblique, intrathecal ridges. Their distinctive features are summarized in Table 1.

The new species is also highly distinctive in that its gonothecae are provided with nematothecae, a situation unknown in any of the Cladocarpus-like species described so far. Moreover, these nematothecae have three different morphologies and are present at different positions on the gonotheca.

\section{Distribution}

Known only from its type locality, off New Caledonia (present study).

Cladocarpus keiensis Schuchert, 2003

Figs 1F, 5

Cladocarpus keiensis Schuchert, 2003: 231, fig. 74.

\section{Material examined}

PACIFIC OCEAN 11 colony, ca $15 \mathrm{~cm}$ high with a $2.3 \mathrm{~cm}$-long side branch, hydrorhiza and gonosome missing; off New Caledonia, stn DW4763; 23ํำ' S, 168 ${ }^{\circ} 15^{\prime}$ E; 192-260 m; 27 Aug. 2016; KANACONO leg.; MNHN-IK-2015-543.

\section{Remarks}

For a description of this species, refer to Schuchert (2003), who documented gonocladia bearing incipient gonothecae only, while the mature ones are still to be described. According to the present material, the plate-like intrahydrothecal septum is pierced in its center by a large, rounded foramen. The passage of the hydranth takes place in front of the septum and its body passes between the two lateral, arched perisarcal ridges.

\section{Distribution}

Kei Islands, Indonesia (Schuchert 2003), New Caledonia (present study). 

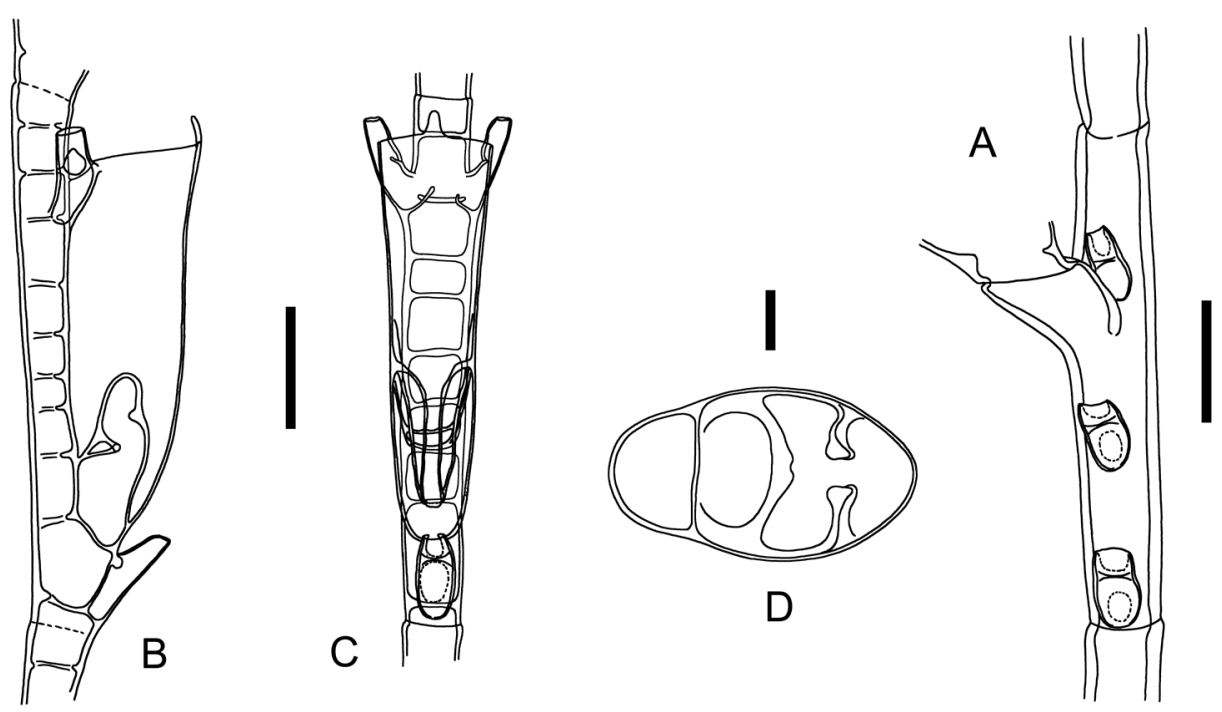

Fig. 5. Cladocarpus keiensis Schuchert, 2003, portion of stem (A), hydrotheca in lateral (B), frontal (C) and apical (D) aspects; all from sample MNHN-IK-2015-543. Scale bars: A-C $=50 \mu \mathrm{m} ; \mathrm{D}=200 \mu \mathrm{m}$.

\section{Cladocarpus partitus sp. nov. urn:1sid:zoobank.org:act:498492D3-3B64-485D-9414-2BD05CF55103}

Figs $6 \mathrm{~A}-\mathrm{B}, 7$

\section{Diagnosis}

Cladocarpus with lightly fascicled, unbranched stems, whose rather long internodes bear a frontal row of 2-3 nematothecae, a lateral apophysis with a basal mamelon, as well as an anterior axillar nematotheca. Cladia relatively spaced from one another. Cormidia elongated, with up to 8 internal septa, 2 abaxial up to 6 adaxial. Hydrotheca deep, mesial nematotheca short, rim with median abaxial cusp, nearly smooth elsewhere; an internal ridge projecting forwards and slightly upwards from the lower fourth of the adaxial wall of hydrotheca, as well as an arched, two-winged septum above, leaving a slit-like, median passage for the hydranth. Phylactocarp borne on stem internode by means of a short apophysis; segmented into moderately-long internodes, each with one frontal, triangular nematotheca; gonothecae on distalmost internodes; tubular, with a main, lateral, subterminal, slit-like aperture, and an inconspicuous, secondary gutter-shaped aperture above.

\section{Etymology}

From the Latin 'partǐor, -ìtus sum, -ìri', meaning 'partitioned', with reference to its hydrothecae that are divided by a transverse, bilobate septum.

\section{Material examined}

\section{Holotype}

PACIFIC OCEAN • 1 colony, ca $6.5 \mathrm{~cm}$ high, hydrorhiza missing; off New Caledonia, stn DW4770; $22^{\circ} 58^{\prime} \mathrm{S}, 168^{\circ} 21^{\prime} \mathrm{E}$; $455-470$ m; 28 Aug. 2016; KANACONO leg.; MNHN-IK-2015-529.

\section{Description}

Colony erect, feather shaped, delicate, ca $6.5 \mathrm{~cm}$ high, hydrorhiza not observed. Stem unbranched although, in the present specimen, the distal part had been partly broken off, but still remained attached, 
and was consequently displaced laterally by a new, regenerative colony tip that has grown up vertically, giving the impression that the old apex is merely a lateral branch; stem fascicled proximally, grading to monosiphonic distally; every additional auxiliary tube adhering to the dorsal side of the preceding one, not forming a beam around the main tube, but resulting in a laterally-flattened structure (Fig. 7B); division into internodes indistinct, except for 3-4 oblique, deeply-cut nodes towards the proximal part of hydrocaulus, passing through all cauline tubes at a time. Equivalents of internodes $700-1050 \mu \mathrm{m} \mathrm{long}$, 200-225 $\mu \mathrm{m}$ wide, composed of 2-3 frontal nematothecae in a row, a short lateral cladial apophysis, a reduced nematotheca (with small, rounded aperture) on an inconspicuous mamelon at its base, as well as an axillar, anterior nematotheca rather lateral to it; there is no dorsal axillar nematotheca. Stem nematothecae large, inverted-triangular, with thick perisarc, apertures distal, wide, with inwardly-
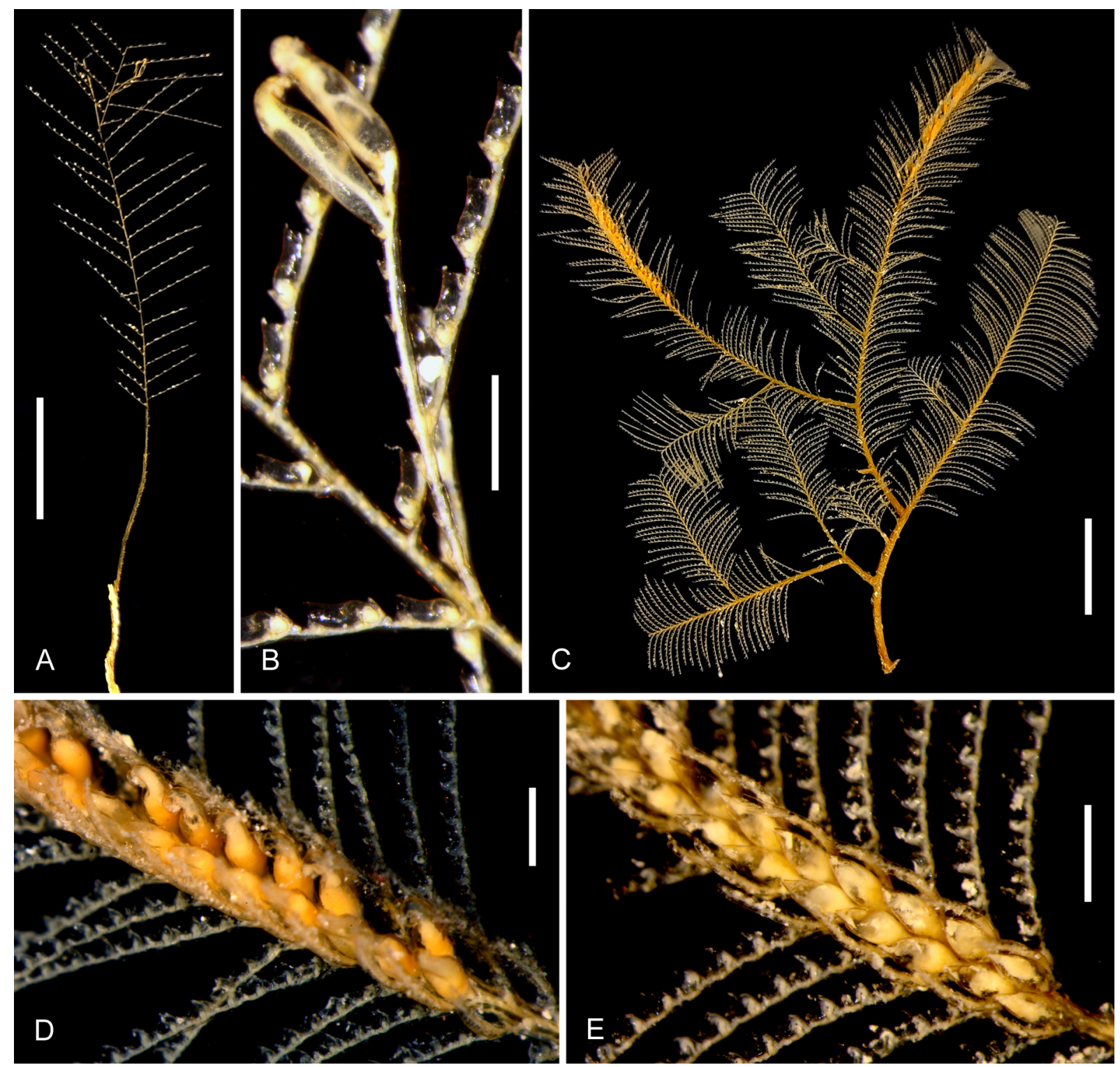

Fig. 6. A-B. Cladocarpus partitus sp. nov., fertile cormoid (A) and phylactocarp (B) from sample MNHN-IK-2015-529 (holotype). - C-E. Cladocarpus pennatus sp. nov., fertile colony (C) and phylactocarp with male gonothecae (D) from sample MNHN-IK-2015-534 (holotype); phylactocarp with female gonothecae from sample MNHN-IK-2015-537 (one paratype). Scale bars: A, C-E = $1 \mathrm{~cm}$; $\mathrm{B}=1 \mathrm{~mm}$. 


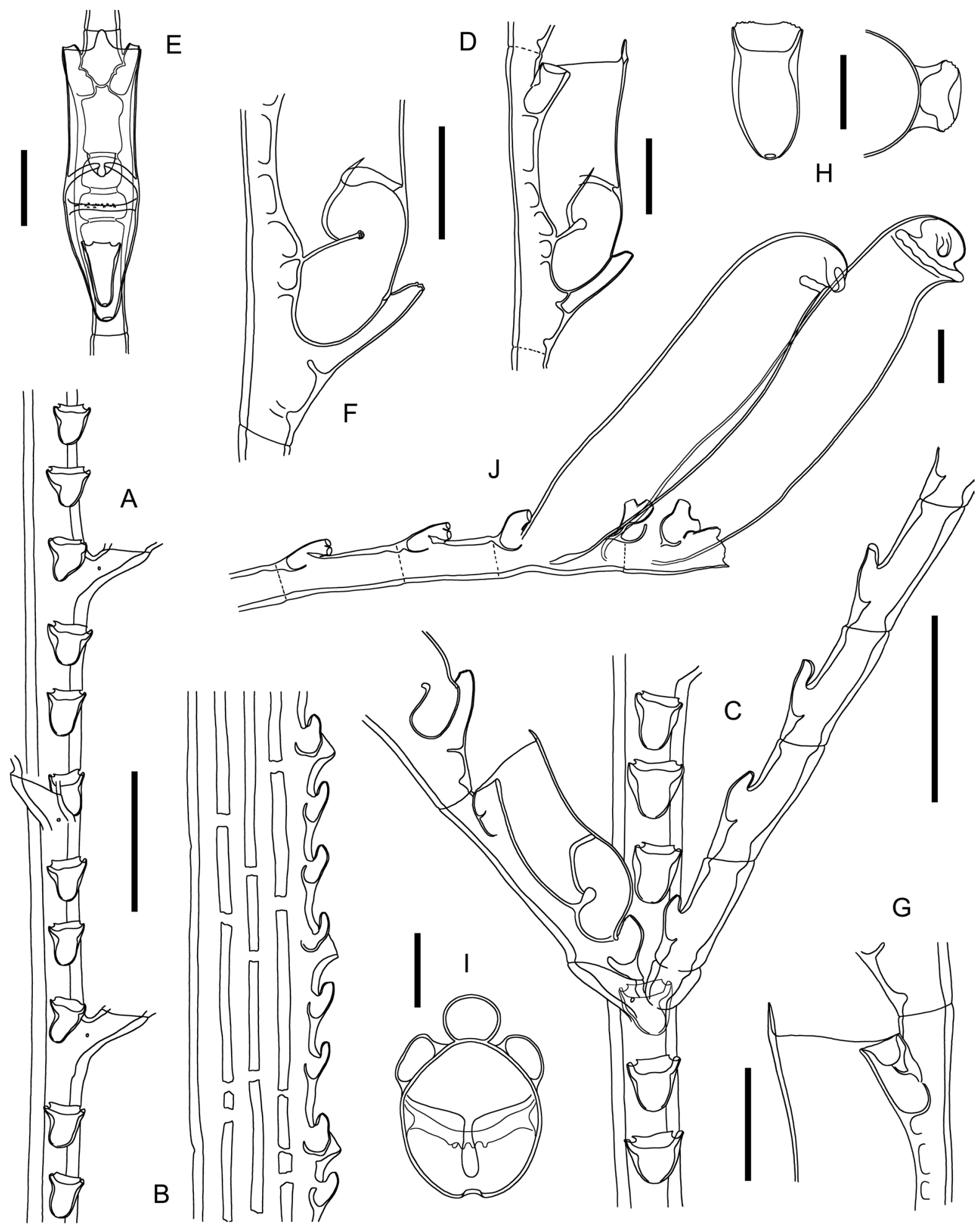

Fig. 7. Cladocarpus partitus sp. nov., from sample MNHN-IK-2015-529. Portions from proximal (A, seen frontally; B, seen laterally) and distal (C, with insertion of phylactocarp) parts of stem. Hydrotheca seen laterally (D) and frontally (E), and details of its basal (F) and distal (G) parts; mesial nematotheca (H) seen frontally (left) and apically (right); internal septa in an apical view of the hydrotheca (I). Distal end of phylactocarp with two gonothecae $(\mathrm{J})$. Scale bars: A-C $=500 \mu \mathrm{m} ; \mathrm{D}-\mathrm{G}, \mathrm{J}=200 \mu \mathrm{m} ; \mathrm{H}, \mathrm{I}=$ $100 \mu \mathrm{m}$. 
rolled abaxial wall, giving the impression that two circular apertures are present laterally; apophyses slightly shifted onto the anterior side of the colony, the two rows of hydrocladia forming an obtuse angle. Cladia relatively spaced from one another, up to $1 \mathrm{~cm}$ long, unbranched, divided into up to 12 cormidia by means of transverse, though not clearly demarcated nodes ( $75-95 \mu \mathrm{m}$ wide), each internode $775-865 \mu \mathrm{m}$ long, accommodating a hydrotheca and its 3 associated nematothecae: one mesial and a pair of laterals; up to 8 intranodal projections of the perisarc, of which 2 are given off from the abaxial side below the hydrothecal base, and up to 6 arise from the dorsal wall of the hydrotheca and project for a short distance into the lumen of the internode. Hydrotheca elongated, 600-635 $\mu \mathrm{m}$ deep, laterallyflattened, ad- and abaxial walls with slight basal bulges; a septum projecting slightly upwards from the lower portion of the adaxial wall reaches up to the middle of the thecal lumen, and is provided anteriorly with a distal swelling scattered with granular projections; a second, lamellar, two-winged septum is given off upwardly from the lateral sides of the hydrotheca at a rather acute angle, then changes its orientation and slightly plunges downwards, attaching its anterior border to the abaxial wall of the theca, leaving a slit-like, median passage between its two lateral 'wings'; hydrothecal aperture 225$230 \mu \mathrm{m}$ wide, rim with a prominent, central, well-developed, abaxial cusp, nearly smooth elsewhere. Mesial nematothecae elongated, rather broad in frontal view, adnate for most of their length, leaving a short $(40-50 \mu \mathrm{m})$ portion free from the base of the corresponding hydrotheca; aperture broad, abaxial wall inwardly-rolled, rim crenelate at corners; mesial nematotheca of first cormidium short, guttershaped and not coalescent with the hydrothecal base. Lateral nematothecae 145-155 $\mu \mathrm{m}$ long, broadly cylindrical, reaching the level of the hydrothecal rim; adaxial wall deeply scooped out, abaxial wall crenelate to wavy. Phylactocarp mounted on a short stem apophysis arising laterally, next to a cladial apophysis, on opposite side; divided into several moderately-long (360-485 $\mu \mathrm{m})$ internodes by means of transverse to slightly oblique nodes, each bearing a frontal nematotheca similar to those of stem, with large apical apertures and inwardly-rolled abaxial walls, giving the impression that the nematothecae are bifid; last couple of internodes additionally provided with a basally concrescent gonotheca; the latter long, tubular (ca $1630 \times 400 \mu \mathrm{m}$ ), tapering below, distally with a main, broad, subterminal, slit-like aperture with flimsy, wavy rim, above which a second, short, slender, gutter-shaped aperture is to be found. Sex undeterminable.

\section{Remarks}

Although not comprehensively described and/or illustrated, especially upon an apical examination of the hydrothecae, the internal septa of Cladocarpus bicuspis (G.O. Sars, 1874) possibly share morphological affinities with those of the present species. Indeed, a transverse septum, originating from the lateroabaxial hydrothecal walls, projects nearly horizontally midway into the lumen, then plunges down so as to meet the distal, swollen border of the adaxial hydrothecal ridge (G.O. Sars 1874: pl. 2 fig. 9; Kramp 1935: fig. 71b; Cornelius 1995: fig. 47c). Frontal views of the hydrotheca illustrated in the literature (Broch 1918: fig. 48c; Schuchert 2001: fig. 114b) do not provide sufficient information on the global aspect of the abaxial projection. Besides this possible common feature, the hydrothecae of C. bicuspis are distinctive through the presence of a median, abaxial pair of marginal cusps, separated from a squared to $\mathrm{V}$-shaped gap prolonged downwards, till the level of abaxial ridge, as a perisarcal thickening; additional features related to its gonosome allow a rapid separation from the present new species (Cornelius 1995).

Also similar seems to be the abaxial septum of Wanglaophenia longicarpa Vervoort \& Watson, 2003, as observed from the illustration in Vervoort \& Watson (2003: fig. 81g). This species, however, possesses hydrothecae with a distinct, abaxial, thorn-shaped crest prolonged downwards as a longitudinal ridge, and its phylactocarp has forked costae provided with hydrothecae (Vervoort \& Watson 2003).

\section{Distribution}

Known only from its type locality, off New Caledonia (present study). 
Cladocarpus pennatus sp. nov. urn:1sid:zoobank.org:act:7E29B1BC-C12D-43BE-8D91-0BB238C6CDBA

Figs 6C-E, 8-9; Table 2

\section{Diagnosis}

Cladocarpus with large, fan-shaped colonies, with strongly fascicled stems and side branches. Nodes rather indistinct, internodes with a proximal, frontal nematotheca, a cladial apophysis with its coneshaped nematotheca, as well as a fronto-axillar nematotheca. Cladia close to one another, divided into short internodes; first internode short, with a nematotheca, but no hydrotheca; remainder of cladium with normal cormidia. Hydrothecae facing backwards with respect to the antero-posterior plane of the colony; sigmoid, variously bulging abaxially from their lower halves; mesial nematotheca conspicuous, half adnate, projecting obliquely forward and upward (shorter and strongly pointing laterally on first cormidium); hydrothecal aperture with a median, triangular cusp and 1-2 pairs of laterals, decreasing in size adaxially; an internal, adaxial septum plunging down into the hydrothecal lumen for half its width. Gonosome composed of gonothecae arising from the cladial apophyses and phylactocarps borne on the first cormidium of a cladium that has lost its proximalmost, nematothecate internode. Phylactocarps elongated, set with consecutive pairs of lateral nematothecae, an additional, median, distal row occasionally present. Gonothecae dimorphic, male tubular, with recurved distal end bearing large aperture flanked by two lobes, female comparatively smaller and fusiform.

\section{Etymology}

From the Latin 'pennātus, $-a,-u m$ ', meaning 'bearing plumes', with reference to the plumose appearance of its colonies.

\section{Material examined}

\section{Holotype}

PACIFIC OCEAN -1 colony, ca $6 \times 6 \mathrm{~cm}$, hydrorhiza missing, bearing male gonothecae; off New Caledonia, stn DW4720; 22 $50^{\prime}$ S, $167^{\circ} 11^{\prime}$ E; 374-400 m; 19 Aug. 2016; KANACONO leg.; MNHN-IK-2015-534.

\section{Paratypes}

PACIFIC OCEAN $\bullet 1$ colony, ca $4.5 \times 6.5 \mathrm{~cm}$, hydrorhiza missing, bearing female gonothecae with welldiscerned oocytes; off New Caledonia, stn DW4720; 22 ${ }^{\circ} 50^{\prime}$ S, $167^{\circ} 11^{\prime}$ E; 374-400 m; 19 Aug. 2016; KANACONO leg.; MNHN-IK-2015-535 - two colonies, ca $8 \times 4.5 \mathrm{~cm}$ and $5 \times 4.5 \mathrm{~cm}$, both without hydrorhizae, but bearing female gonothecae; off New Caledonia, stn DW4707; 22 $46^{\prime}$ S, $167^{\circ} 23^{\prime} \mathrm{E}$; 291-259 m; 17 Aug. 2016; KANACONO leg.; MNHN-IK-2015-537.

\section{Additional material}

PACIFIC OCEAN $\bullet 1$ colony, ca $11 \times 8.5 \mathrm{~cm}$, bearing female gonothecae; off New Caledonia, stn CP4704; $22^{\circ} 46^{\prime}$ S, $167^{\circ} 19^{\prime}$ E; 365-356 m; 17 Aug. 2016; KANACONO leg.; MNHN-IK-2015-531 • 1 young, unbranched, sterile colony, $7 \mathrm{~cm}$ high, hydrorhiza missing; off New Caledonia, stn DW4762; $23^{\circ} 16^{\prime} \mathrm{S}$, 168 $06^{\prime}$ E; 810-805 m; 26 Aug. 2016; KANACONO leg.; MNHN-IK-2015-532 • 1 colony fragment, ca $3.8 \times 2 \mathrm{~cm}$, bearing female gonothecae; off New Caledonia, stn DW4713; $22^{\circ} 47^{\prime} \mathrm{S}, 167^{\circ} 47^{\prime} \mathrm{E}$; 356-380 m; 18 Aug. 2016; KANACONO leg.; MNHN-IK-2015-533 3 colonies, ca $10 \times 7$ cm, $8 \times$ $5.5 \mathrm{~cm}$ and $10 \times 7 \mathrm{~cm}$, with female gonothecae, 1 colony, $12 \times 4 \mathrm{~cm}$, without gonothecae; off New Caledonia, stn CP4675; $22^{\circ} 50^{\prime} \mathrm{S}, 1^{\circ} 7^{\circ} 30^{\prime} \mathrm{E}$; 350-366 m; 13 Aug. 2016; KANACONO leg.; MNHNIK-2015-536 3 colonies with or without hydrorhizae and no gonothecae, ca $7.5 \times 4.5 \mathrm{~cm}, 5.5 \times 2 \mathrm{~cm}$, and $5.5 \times 7.5 \mathrm{~cm}$, respectively, 1 colony, ca $5 \times 6.5$, without hydrorhiza and starting to reproduce (only phylactocarps but no gonothecae are present), 1 male colony, $5 \times 3 \mathrm{~cm}$, hydrorhiza missing, 


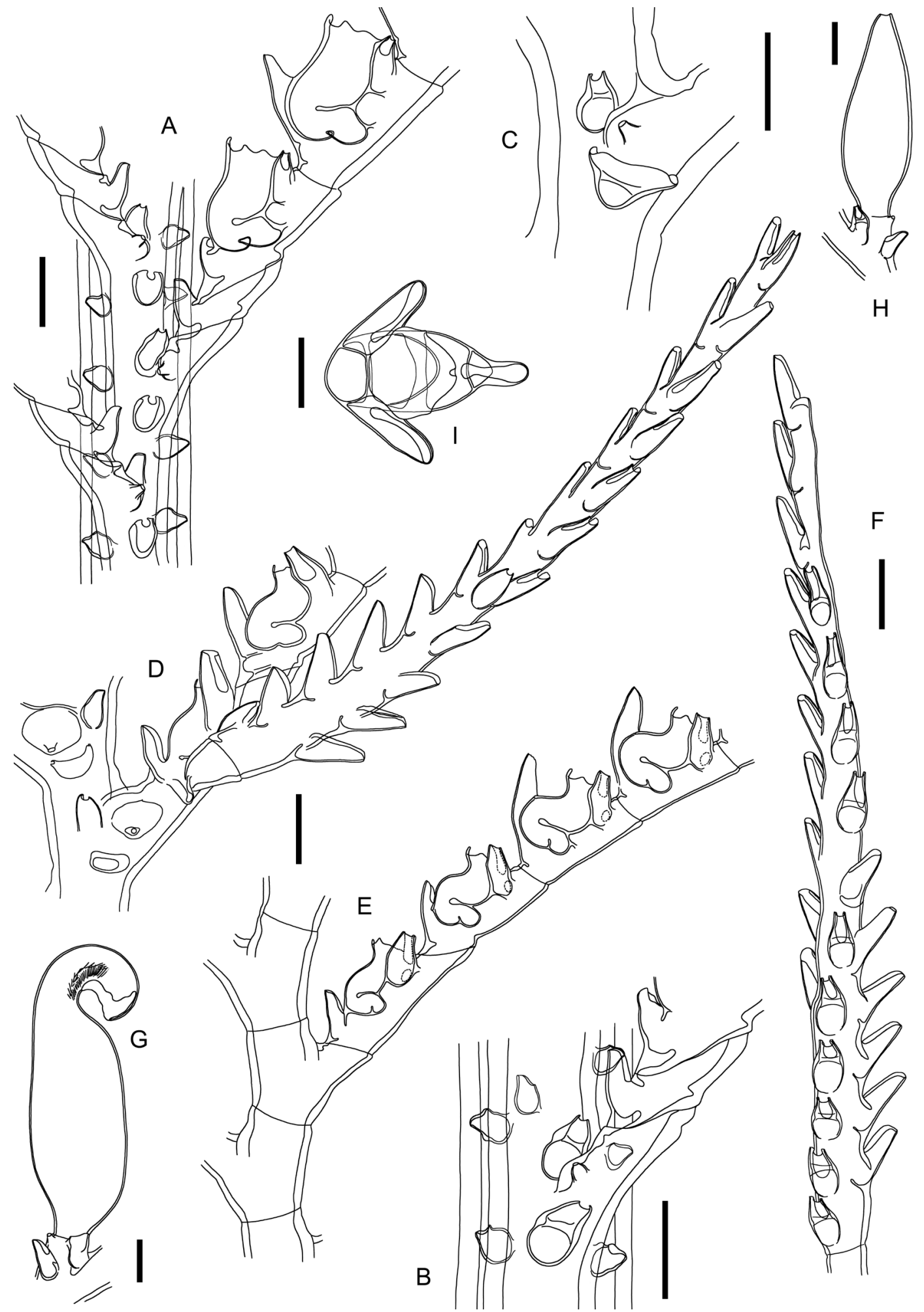

Fig. 8. Cladocarpus pennatus sp. nov. (part). Portion of stem showing insertions of successive cladia (A) and details of apophysis with its associated nematothecae (B-C). Proximal portions of fertile cladia in frontal (D, with phylactocarp) and dorsal (E, phylactocarp on first cormidium not shown) aspects. Phylactocarp (F). Male $(\mathrm{G})$ and female $(\mathrm{H})$ gonothecae. Hydrotheca seen apically (I). From samples MNHN-IK-2015-532 (A-C), MNHN-IK-2015-533 (E, I), MNHN-IK-2015-537 (G) and MNHN-IK-2015-540 (D, F, H). Scale bars: $G=100 \mu \mathrm{m}$; A-F, H, I = $200 \mu \mathrm{m}$. 
upper part of 1 large colony, ca $4.2 \times 6 \mathrm{~cm}$, with male gonothecae; off New Caledonia, stn DW4717; $22^{\circ} 44^{\prime} \mathrm{S}, 1^{\circ} 7^{\circ} 11^{\prime} \mathrm{E}$; 336-361 m; 19 Aug. 2016; KANACONO leg.; MNHN-IK-2015-538 • 1 long fragment, $2.7 \mathrm{~cm}$, without gonothecae, with strongly bent hydrothecae and hypertrophied nematothecae;

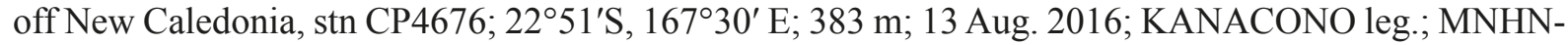
IK-2015-539 2 colony fragments, ca $4 \times 2 \mathrm{~cm}$ and $2.4 \mathrm{~cm}$, respectively, both with male gonothecae, 1 unbranched colony, $6 \mathrm{~cm}$ high, without gonothecae; off New Caledonia, stn DW4679; $22^{\circ} 49^{\prime} \mathrm{S}$, 167³3' E; 245-249 m; 13 Aug. 2016; KANACONO leg.; MNHN-IK-2015-540 • 1 colony, ca $7 \times 5$ cm, with female gonothecae, 1 colony, ca $6.5 \times 4.5 \mathrm{~cm}$, hydrorhiza and gonothecae missing; off New
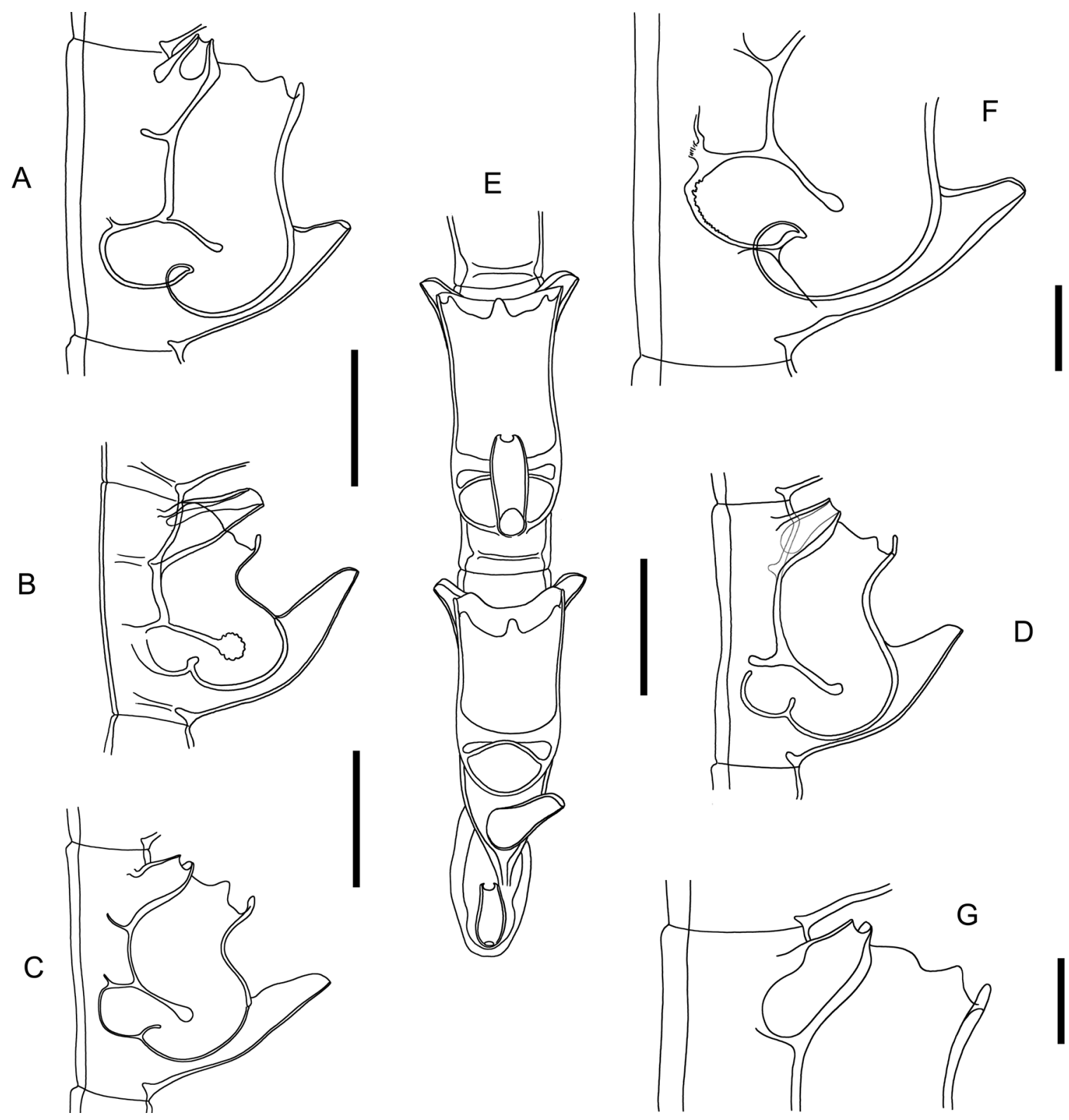

Fig. 9. Cladocarpus pennatus sp. nov. (continued). A-E. Hydrothecae from different colonies seen in lateral view (A-D), to show variation in abaxial curvature, and proximalmost part of a hydrocladium seen frontally (E). F-G. Details of the basal (F) and distal (G) parts of a hydrotheca seen laterally. From samples MNHN-IK-2015-531 (C), MNHN-IK-2015-532 (A, E-G), MNHN-IK-2015-536 (D) and MNHN-IK-2015-539 (B). Scale bars: A-E $=200 \mu \mathrm{m} ; \mathrm{F}-\mathrm{G}=100 \mu \mathrm{m}$. 


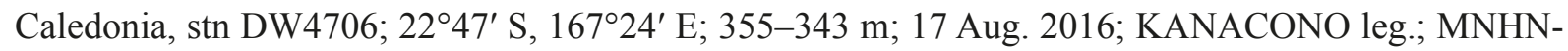
IK-2015-541 1 colony, ca $8 \times 4 \mathrm{~cm}$, without hydrorhiza, bearing male gonothecae; off New Caledonia, stn DW4708; 224ㄴ ' S, 167²1' E; 71-68 m; 17 Aug. 2016; KANACONO leg.; MNHN-IK-2015-542 • 1 unbranched colony, ca $5 \mathrm{~cm}$ high, without hydrorhiza and gonothecae; off New Caledonia, stn DW4745; 225ㄱ' S, 167³9' E; 310-403 m; 23 Aug. 2016; KANACONO leg.; MNHN-IK-2014-2594.

\section{Description}

Colonies erect, fan-shaped, up to $11 \mathrm{~cm}$ high and $8.5 \mathrm{~cm}$ wide, arising from rhizoid stolon composed of numerous branching, anastomosing, contiguous fibers firmly anchoring the whole structure on its substrate. Stems strongly fascicled, branched irregularly with a tendency to alternate, main stem supported dorsally by beam of auxiliary tubes, each provided with a longitudinal row of deeply-immersed, saccate nematothecae, having only their distal parts, bearing the apertures, protruding from the perisarc. There are no proximal oblique nodes passing through the fascicled stem; main tube with indistinct division into internodes, except for the distalmost parts of a colony, where the perisarc is thinner, and where weak transverse node delimit very short internodes; the latter composed of a proximal, frontal nematotheca, a laterally-directed cladial apophysis with its reduced conical nematotheca (with small, rounded aperture), and a second, frontal (axillar) nematotheca rather lateral to the apophysis; stem nematothecae elongated, with gutter-shaped apertures, occasionally inverted-triangular, with wide distal apertures and backwardly-rolled abaxial walls. Apophyses alternate along the stem, well-developed, delimited from the corresponding cladium by a deeply-cut, very oblique node; cladia close to one another, up to $7 \mathrm{~mm}$ long, slightly convex, proximally pointing upwards and distally downwards, the two rows coplanar; first cladial internode very short, ahydrothecate, but provided with a frontal, gutter-shaped nematotheca, ending in oblique node, separating it from the remainder of cladium, the latter comprising a regular succession of short internodes delimited by means of transverse nodes (100-115 $\mu \mathrm{m}$ wide); each internode 350-365 $\mu \mathrm{m}$ long, with a hydrotheca and its 3 associated nematothecae: one mesial and a pair of laterals; through a torsion of the cladium at its insertion on the corresponding apophysis, all hydrothecae face backwards with respect to the antero-posterior plane of the colony. Hydrothecae 260 $270 \mu \mathrm{m}$ deep, S-shaped, with thick abaxial wall, with an internal septum given off from the lower $1 / 4$ of the cavity and projecting slightly downwards so as to reach about the middle of the thecal lumen, ending distally in a perisarc plug; aperture ca $160 \mu \mathrm{m}$ wide, rim with a central, prominent, triangular, abaxial cusp, continued laterally with 1-2 additional cusps decreasing in size adaxially. Mesial nematotheca adnate for $3 / 4$ to $1 / 2$ of its length to the hydrothecal base, free part $115-125 \mu \mathrm{m}$ long, aperture adaxial and gutter-shaped over entire length of free part; lateral nematothecae long (ca $145 \mu \mathrm{m}$ ), tubular, pointing out- and upwards, adaxial wall deeply scooped out. First cladial hydrotheca with comparatively shorter mesial nematotheca, given off from below its base, and distinctly pointing towards the dorsal side of the colony. Gonosome composed of phylactocarps, each associated with one gonotheca; gonothecae given off from the cladial apophyses just above the conical nematotheca and lateral to the distalmost internodal stem nematotheca; phylactocarps given off from cladia modified proximally as follows: the proximalmost ahydrothecate internode carrying the single, frontal nematotheca is replaced by a complete cormidium delimited by very oblique nodes; its mesial nematotheca is comparatively shorter than the subsequent ones, is given off from below the hydrothecal base, and is distinctly shifted on to the dorsal side of the colony; the second cormidium, also complete, is delimited proximally by an oblique node and distally by the first transverse node of the cladium; its mesial nematotheca is more elongated than that of the first cormidium and surpasses, for a certain distance, the hydrothecal base, but is still slightly shifted laterally; the third and subsequent cormidia are similar to those of a normal hydrocladium, with well-defined, straight mesial nematothecae. The phylactocarps are given off from the first cormidium, lateral to and above the mesial nematotheca, towards the front of the colony, by means of a short, conical apophysis delimited distally by transverse node, and having a long, guttershaped nematotheca at its base; phylactocarp composed of a double row of nematothecae, 6-10 in female colonies and up to 30 in males; in the latter, the double row is often supplemented distally 
Table 2. Cladocarpus-like hydroids with S-shaped hydrothecae provided with an adaxial septum, and their distinctive features with respect to Cladocarpus pennatus sp. nov.

\begin{tabular}{ll}
\hline Nominal species & Brief description, with emphasis on the distinctive features, and geographical distribution \\
\hline & $\begin{array}{l}\text { Stem internodes with } 1 \text { frontal nematotheca and } 2 \text { axillar, flanking each cladial apophysis on both } \\
\text { Sides of the stem; no mamelon; cormidia long, slender, with up to } 9 \text { intranodal septa, one of which is }\end{array}$ \\
cartieri & $\begin{array}{l}\text { proximal and abaxial; hydrothecae elongated, adaxial septum short, aperture rounded, rim entirely } \\
\text { Bedot, } 1921\end{array}$ \\
$\begin{array}{l}\text { smooth; mesial nematotheca a short distance below hydrothecal base, laterals elongate, overtopping } \\
\text { aperture (Ramil \& Vervoort 1992b). Distribution: Azores, Mid Atlantic Ridge (Calder \&Vervoort }\end{array}$ \\
1998).
\end{tabular}

Stem internodes with 2-5 frontal nematothecae, a fronto-axillar one, but no conical nematotheca on cladial apophysis; cormidia with 6-8 intranodal ridges; hydrothecae elongated, adaxial septum set

Streptocaulus dollfusi

(Billard, 1924) upwards, rim with 1 median abaxial cusp variably developed, elsewhere smooth to weakly undulated; mesial nematotheca below hydrothecal base, laterals facing upwards and forwards, overtopping hydrothecal rim; phylactocarps borne laterally on $1^{\text {st }}$ hydrotheca, composed of a succession of short internodes with distal pairs of nematothecae (Ansín Agís et al. 2001); gonothecae on phylactocarps: female elongated, aperture lateral, subterminal, male fusiform, distally truncate (Billard 1934). Distribution: eastern Atlantic from the Bay of Biscay to Morocco (Ansín Agís et al. 2001).

Stem with 2-4 frontal nematothecae (each with 4 apertures) between successive cladial apophyses, single axillar nematotheca, and no conical nematotheca on apophysis; cormidia long, S-shaped,

Cladocarpus millardae Vervoort, 1966 with centrally-placed hydrotheca; mesial nematotheca with 4 apertures, seated below the hydrothecal base; lateral nematothecae antler-shaped, with 5-7 apertures; hydrothecal rim without cusps; internodes of phylactocarp with 2 lateral nematothecae, each with 2-3 apertures; gonotheca globular, distally truncate. Distribution: Mozambique, NE coast of South Africa (Millard 1975).

Stem internodes with 1 frontal nematotheca, single axillar nematotheca, and no conical

Cladocarpus paraventricosus

Ramil \&

Vervoort, 1992 nematotheca on apophysis; cormidia long, slightly sigmoid, with centrally-placed hydrotheca; mesial nematotheca below the hydrothecal base, laterals long, tubular, surpassing the rim; margin with median, conspicuous cusp and 5 pairs of laterals, slightly marked; intrathecal septum short, projecting upwards; phylactocarps borne on first cormidium, branched pseudodichotomously, a gonotheca after each ramification; gonotheca ovoid, aperture lateral, subapical. Distribution: Strait of Gibraltar (Ramil \& Vervoort 1992b).

Stem with 1-5 frontal nematothecae between successive cladial apophyses, with single axillar nematotheca, and no conical nematotheca on apophysis; cormidia long, slightly sinusoid,

Cladocarpus sinuosus hydrotheca placed in middle portion, elongated, mesial nematotheca below the hydrothecal base; rim of hydrotheca, besides the median abaxial cusps, with faintly sinuous lateral edges; internodes Vervoort, 1966 of phylactocarp with two very long, curved nematothecae; gonothecae ovoid with truncate distal end (Vervoort 1966; Millard 1975). Distribution: Alboran Sea, Guinea Bissau, South Africa (Ansín Agís et al. 2001).

Main tube of the stem with intranodal septa, 1-3 frontal nematothecae between successive cladial

Cladocarpus unicornus Millard, 1975 with basal abaxial bulge capped by short solid horn of perisarc; mesial nematotheca free from hydrotheca, lateral nematothecae elongated, with 3 apertures, margin with median, abaxial, inturned cusp, elsewhere smooth. Distribution: endemic to South Africa (Millard 1975).

Stem internodes with 3-8 frontal nematothecae, 2 axillar nematothecae, and a mamelon on each hydrocladial apophysis; cormidia fairly long, with up to 9 intranodal septa; hydrotheca ventricose,

Cladocarpus ventricosus Allman, 1877 adaxial ridge directed upwards; mesial nematotheca below the hydrothecal base or slightly surpassing $i t$; lateral nematothecae overtopping hydrothecal rim; rim with median abaxial cusp and slightly crenate edges; gonothecae borne on stem, oval, aperture lateral, subterminal; phylactocarp borne on first cormidium, antler-shaped, with 3-4 branchlets (Bogle 1975; Ramil \& Vervoort 1992b). Distribution: Florida and Straits of Florida (Bogle 1975).

Stem with at least one frontal nematotheca, a pair of axillar nematothecae, and a mamelon; internodes as long as to accommodate a hydrotheca and its 3 nematothecae; hydrotheca fairly long,

Cladocarpoides adaxial septum projecting upwards, mesial nematotheca adnate to lower abaxial thecal wall, laterals yucatanicus Bogle, 1984 overtopping margin; rim sinuous, except for the median, abaxial cusp; gonothecae obovate, borne on base of stem apophyses; phylactocarp borne on first cormidium, corbula-like, costae antler-shaped, with associated hydrotheca and terminated in nematophorous spike. Distribution: Yucatan Channel (Bogle 1984). 
by a number of additional nematothecae situated dorsally in a median row. Colonies dioecious; the gonothecae occur in groups towards the distal parts of the colonies, and are given off simultaneously from numerous consecutive apophyses of the branches; male gonothecae large (ca $1395 \times 460 \mu \mathrm{m}$ ), tapering below, distally narrowing to a downwardly-curved neck, with broad aperture flanked by a pair of lobes; female comparatively smaller (ca $955 \times 330 \mu \mathrm{m}$ ), fusiform, with minute (ca $35 \mu \mathrm{m}$ wide), apical aperture, despite the much larger size of the oocytes.

\section{Remarks}

Several Cladocarpus-like hydroids possess S-shaped hydrothecae provided with an adaxial septum, similar to those of $C$. pennatus sp. nov. However, there are morphological features enabling their specific separation, and these are summarized in Table 2.

The male gonothecae of the new species recall those of Wanglaophenia longicarpa Vervoort \& Watson, 2003 (see Vervoort \& Watson: fig. 81h), but the carinate hydrothecae and the forked phylactocarps bearing hydrothecae (Vervoort \& Watson 2003) of the latter readily distinguishes these hydroids.

\section{Distribution}

Known only from off New Caledonia (present study).

Genus Gymnangium Hincks, 1874

Gymnangium expansum (Jäderholm, 1903)

Fig. 10

Gymnangium expansum - Vervoort 1966: 165, figs 65-66. — Rees \& Vervoort 1987: 163, fig. 38a-b. — Vervoort \& Watson 2003: 289, figs 68g, 69a.

\section{Material examined}

PACIFIC OCEAN 11 colony, ca $10 \mathrm{~cm}$ high, lightly fascicled, fertile; off New Caledonia, stn DW5007; $22^{\circ} 12^{\prime} \mathrm{S}, 1^{\circ} 9^{\circ} 02^{\prime} \mathrm{E}$; 290-750 m; 19 Sep. 2017; KANADEEP leg.; MNHN-IK-2015-515 • 1 colony, ca $10.5 \mathrm{~cm}$ high, lightly fascicled, sterile; off New Caledonia, stn DW4777; $23^{\circ} 03^{\prime} \mathrm{S}, 168^{\circ} 16^{\prime} \mathrm{E}$; 330-353 m; 28 Aug. 2016; KANACONO leg.; MNHN-IK-2015-516 • two sterile stems, the first ca $16 \mathrm{~cm}$ high and monosiphonic, the second ca $20 \mathrm{~cm}$ high and lightly fascicled; off New Caledonia, stn DW4711; 22 $47^{\prime}$ S, $167^{\circ} 24^{\prime}$ E; 335-338 m; 18 Aug. 2016; KANACONO leg.; MNHN-IK-2015-517 • 1 colony, ca $16 \mathrm{~cm}$ high, lightly fascicled, sterile; off New Caledonia, stn CP4674; $22^{\circ} 48^{\prime} \mathrm{S}, 1^{\circ} 7^{\circ} 29^{\prime} \mathrm{E}$; 311-302 m; 13 Aug. 2016; KANACONO leg.; MNHN-IK-2015-518 • 1 colony, ca $12 \mathrm{~cm}$ high, lightly

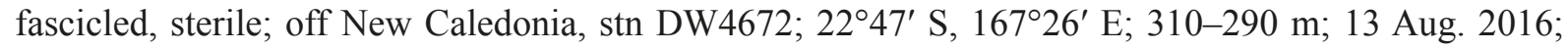
KANACONO leg.; MNHN-IK-2015-521.

\section{Remarks}

For a description of this species, refer to Vervoort (1966) and Rees \& Vervoort (1987); a quite recent synonymy is given in Vervoort \& Watson (2003). In these accounts, only slightly bent hydrothecae, whose nematothecae have single apical apertures, were documented, not reaching the extreme degree of curvature (aperture parallel to long axis of the internode) met with in material MNHN-IK-2015-516, in which, additionally, the mesial nematothecae display 4-6 frontal apertures, while the pairs of laterals have bifid apertures. In contrast, the material MNHN-IK-2015-515 has less curved hydrothecae (their apertures form an angle of $45^{\circ}$ with the long axis of the internode), but their mesial nematothecae still display 2-3 frontal apertures, while the laterals possess only one. An intermediate situation is met with in sample MNHN-IK-2015-518, in which the hydrothecal apertures form an angle of ca $70^{\circ}$ with the 
internode and the mesial nematothecae possess 1-2 frontal apertures, while the laterals have only one. Bifid mesial nematothecae were observed so far in specimens from Japan studied by Schuchert (2015).

In all samples examined the branching pattern is 'trifid', with either mono- (the $16 \mathrm{~cm}$-high colony from sample MNHN-IK-2015-517) or lightly polysiphonic (all remaining material) stems; in addition, their hydrothecae are free from their corresponding internodes for ca $1 / 3$ of their adaxial length, fitting the original account by Jäderholm (1903).

There is no thorough description available of the mode of branching in this species, especially at microscopic level. The original account is quite evasive ("Die Verästelung ist sehr regelmässig und characteristisch. Die nach allen Seiten gerichteten Äste sitzen fast immer zu zweien zusammen, sind sehr deutlich spiralförmig angeordnet und nach aussen gebogen" [The branching is very regular and characteristic. The branches are directed to all sides, almost always they are given off in pairs, are arranged in an obvious spiral, and are bent outwards]). However, Jäderholm (1903: pl. 14 fig. 5) provides a comprehensive illustration of the macroscopic appearance of a typical colony. According to his figure, a pair of plumes is given off at each geniculation of the stem, the successive pairs facing outwards with respect to the spiral built up by the stem.

Subsequent accounts seem to provide rather divergent data. Indeed, the material studied by Stechow (1909: 103, fig. 8) was devoid of the characteristic spiral growth pattern, the main stem giving rise, here and there, to secondary branches that further divide trichotomously. The colony studied by Billard (1918: 25, as Halicornaria sibogae) formed a helicoid sympodium ("Colonie [...] ramifiée en sympode hélicoïde"), thus partly agreeing with the type, although nothing is said about its branching pattern. The account given by Vervoort (1966: 165) ("The structure of the colony is sympodially [sic]: the main axis is formed by the basal parts of successive plumes, arranged in spiral fashion, each succeeding plume rising about $8 \mathrm{~mm}$ from the base of the preceding plume") does not conform with the structure of the type either since, at each geniculation, only one plume, instead of two, is given off. Rees \& Vervoort (1987) observed a "Sympodially built stem with helically arranged, unbranched plumes ..." in their material, resembling those examined earlier by Vervoort (1966).

On the other hand, the colony illustrated by Rho \& Park (1980: pl. 9 fig. 1) is undoubtedly similar to that of the type, despite their description (Rho \& Park 1980: 27) providing only limited details: "Colonies large, not fascicled, spirally branched. The hydrocaulus [is] divided into regular internodes, zigzagshaped".

Finally, Vervoort \& Watson (2003: 289) claim that they "have little to add to the descriptions of this characteristic species given by previous authors".

As noted above, the branching pattern met with in the present material from New Caledonia is superficially trifid, as follows: the stem is geniculate and describes a spiral; at more or less regular intervals, the main tube bifurcates at each geniculation: in the exact continuation of the long axis of the original portion before the geniculation, it is prolonged as a plume (bearing hydrocladia), while the divergent part continues, slightly inclined (with respect to the preceding longitudinal axis), as the main stem proper; from the base of the divergent portion of the stem, two (originally twin) tubes are given off: one runs downwards along the preceding portion of the stem below the geniculation (bringing polysiphony to the colony), while the other is given away upwards, forming a second plume (bearing hydrocladia) (Fig. 10A).

In this context, the specific separation between G. expansum and its closest congener, Gymnangium tubulifer (Bale, 1914), seems to rely exclusively on the appearance of the colonies resulting from their mode of branching. When describing his species, Bale (1914) referred to the structure of the colony of 
G. vegae (Jäderholm, 1903), as did Vervoort \& Watson (2003), who stated that the stem of G. tubulifer "... is geniculate and more or less spiral, composed of the proximal parts of stem elements that at each geniculation turn aside to form a branch. At the same place the proximal element splits off to form 3 ramifications of which [one] continues as the "stem", [one] as a branch pointing away from the original element, and [one] as a downwardly directed tube, covering the more proximal parts of the "stem"". This results in a colony whose distinctive appearance is depicted by Jäderholm (1903: pl. 15 fig. 1).
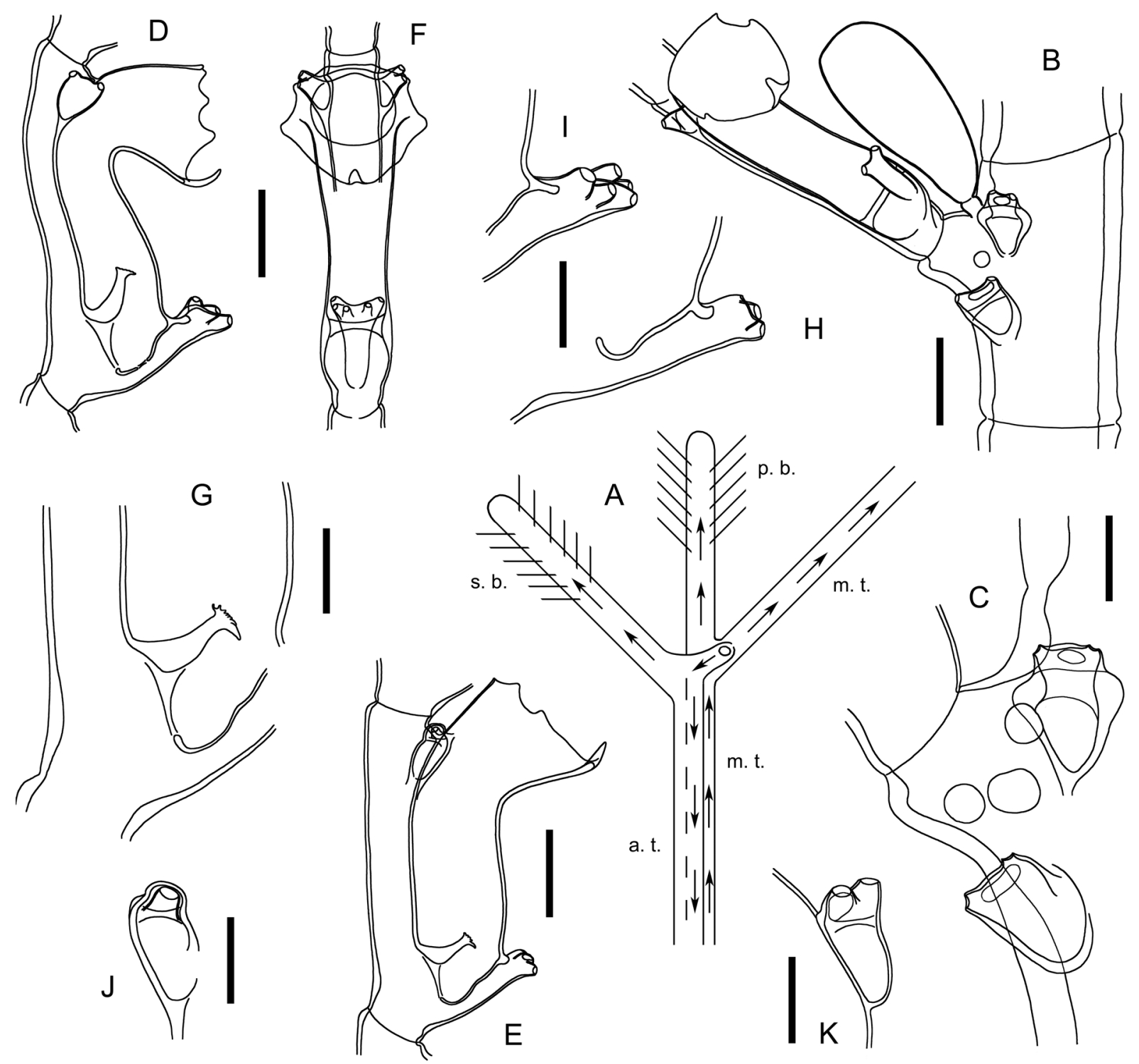

A p. b.

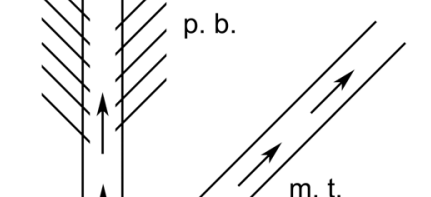


In a molecular study by Ronowicz et al. (2017), G. expansum is shown to cluster with members of the genus Gymnangium Hincks, 1874 instead of with Taxella Allman, 1874, in spite of the colony structure showing obvious affinities with the latter. As noted by these authors, Stechow (1921) proposed a new genus, Halicetta, to accommodate G. expansum, with the following diagnosis: "hydrothecae elongated, curved but not bent, with no abaxial septum". This, however, does not differ much from characters of Taxella, even though emphasis was placed on characters of the gonosome in particular. A more comprehensive analysis is necessary to elucidate the generic affinities of Jäderholm's (1903) hydroid.

\title{
Distribution
}

Scattered records from the tropical and subtropical Indian and Pacific Oceans, from Zanzibar to Japan (Vervoort \& Watson 2003).

Genus Lytocarpia Kirchenpauer, 1872

Lytocarpia brevirostris (Busk, 1852)

Fig. $11 \mathrm{~A}$

Lytocarpia brevirostris - Di Camillo et al. 2011: 525, figs 2c, 3b, f, 6d, 7-8.

\section{Material examined}

PACIFIC OCEAN - several plumes branched or unbranched, $1.8-4.5 \mathrm{~cm}$ high, of which one bears a young corbula; off New Caledonia, stn DW4774; 2301' S, 168 $13^{\circ}$ E; 100-90 m; 28 Aug. 2016; KANACONO leg.; MNHN-IK-2015-514.

\section{Remarks}

For a recent description of this well-known species, refer to Di Camillo et al. (2011), who also provided an extensive synonymy.

\section{Distribution}

Widespread in tropical parts of the Indian Ocean, from Africa to Indonesia, and the northeastern South Pacific (Di Camillo et al. 2001).

\author{
Lytocarpia fragilis sp. nov. \\ urn:lsid:zoobank.org:act:92370DAB-142D-4322-8CA0-DE8B96EA9CD4
}

Figs $11 \mathrm{~B}-\mathrm{K}, 12 \mathrm{~A}-\mathrm{C}$

\section{Diagnosis}

Lytocarpia with moderately tall, delicate colonies, with lightly fascicled, unbranched stems, divided into rather long internodes, each comprising 2-3 frontal nematothecae in a row, a lateral apophysis supporting a cladium with its conical nematotheca, and a couple of axillar nematothecae flanking the apophysis on each side of the stem. Cladia fairly close to one another, cormidia moderately long, with 6 intranodal septa, hydrotheca occupying distal 3/4. Hydrotheca distinctly S-shaped, swollen basally, mesial nematotheca adnate for most of its length, free part projecting nearly upwards, and provided with large aperture behind an inwardly-rolled abaxial wall; lateral nematothecae tubular, with adaxially scooped walls, overtopping hydrothecal aperture. Rim with rounded-triangular median cusp, edges with two low, triangular cusps prolonged adaxially by a mere undulation. Gonosome an open corbula, distally on cladia, each internode with a costa and an axillar nematotheca; costae with a basal hydrotheca and a short appendage comprising 3-4 pairs of laterally-placed nematothecae; gonothecae lenticular. 


\section{Etymology}

From the Latin 'frăgillis', meaning 'frail', with reference to the delicate appearance of its colonies.

\section{Material examined}

Holotype

PACIFIC OCEAN - 1 colony, devoid of its distal part, ca $7.5 \mathrm{~cm}$ high, fertile; off New Caledonia,

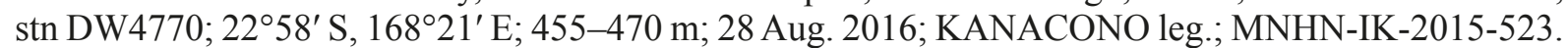

\section{Description}

Colony erect, of a delicate appearance, comprising a single plume, originally taller than the $7.5 \mathrm{~cm}$ high fragment left after the breakage and subsequent loss of its distal part; arising from a rhizoid stolon firmly attached to hard substrate. Stem unbranched, lightly fascicled, grading to monosiphonic distally;

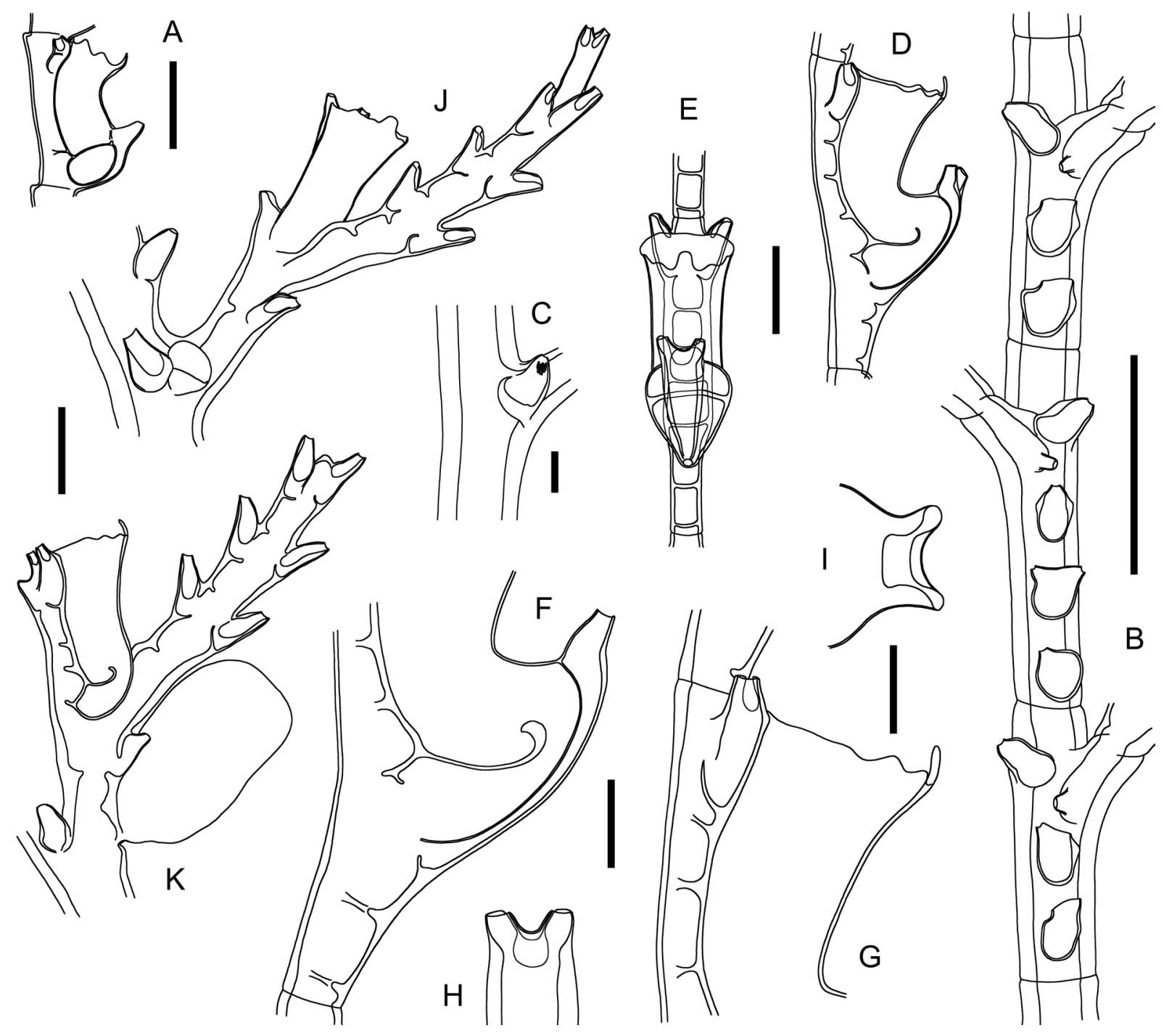

Fig. 11. A. Lytocarpia brevirostris (Busk, 1852), hydrotheca from sample MNHN-IK-2015-514. B-K. Lytocarpia fragilis sp. nov., from sample MNHN-IK-2015-523. A-B. Portions of stems in frontal (B) and dorsal (C) aspects. D-G. Hydrotheca seen laterally (D) and frontally (E), and details of its basal (F) and distal (G) parts, both in lateral view. H-I. Distal part of mesial nematotheca seen frontally $(\mathrm{H})$ and apically (I). J-K. Two corbulacostae. Scale bars: B $=500 \mu \mathrm{m}$; A, D-E, J-K $=200 \mu \mathrm{m} ; \mathrm{C}, \mathrm{F}-\mathrm{I}=100 \mu \mathrm{m}$. 
main tube composed of a long $(3.5 \mathrm{~cm})$ proximal part devoid of hydrocladia but bearing large, saccate nematothecae in a single, frontal row, and a shorter part bearing cladia; both parts are separated by a short intervening prosegment with one frontal nematotheca, delimited at both ends by very oblique, deeply-cut nodes. Upper part divided, sporadically, into long segments by means of a few oblique nodes; segments further divided into regular, moderately long $(680-840 \mu \mathrm{m})$ internodes delimited by transverse nodes (150-170 $\mu \mathrm{m}$ wide), inconspicuous wherever the perisarc is thick, but becoming obvious in youngest parts; each internode with 2-3 frontal nematothecae in a single row, a short cladial apophysis with its basal, simple nematotheca mounted on an inconspicuous mamelon, a nematotheca lateral to the apophysis (axillar, in front of stem), as well as an axillar nematotheca on dorsal side of the stem. Frontal nematothecae large, saccate, with wide aperture behind, sometimes giving the impression that one or two lateral apertures are present, due to their inwardly-rolled abaxial walls. Cladia alternate, fairly close to one another on each row, up to $1.3 \mathrm{~cm}$ long, composed of up to 18 cormidia. The latter moderately long (705-715 $\mu \mathrm{m}$ long, 65-70 $\mu \mathrm{m}$ wide at node), accommodating a hydrotheca in their distal $3 / 4$, and its 3 associated nematothecae: one mesial and a pair of laterals; 6 intranodal projections of the perisarc: 4 given off from the adaxial wall of the hydrotheca, while the remaining 2 from the abaxial perisarc of the internode. Hydrotheca 475-485 $\mu \mathrm{m}$ deep, S-shaped in lateral view, lower half distinctly swollen when seen frontally; mesial nematotheca adnate for most of its length, leaving a short, free, bifid portion reaching the middle of the theca; aperture wide, abaxial wall inwardly-rolled; lateral nematothecae conical, with gutter-shaped apertures in their adaxial wall; hydrothecal aperture 230-240 $\mu \mathrm{m}$ wide, rim with a prominent, rounded, abaxial cusp, lateral edges with two pairs of low, triangular cusps, prolonged adaxially by a mere undulation of the margin. Gonosome an open corbula on the modified distal portion of a cladium, after a sequence of 3-6 normal cormidia proximally; rachis divided into short internodes by means of transverse nodes; each internode with a costa (there is no distinct apophysis supporting it; costae alternate) and a large, saccate nematotheca (with gutter-shaped aperture) lateral to it; unlike the subsequent ones, the first internode of the corbula possesses an axillar nematotheca at junction between the insertion of costa and the internode; costae composed of a modified hydrotheca that retains its lateral nematothecae at their normal place, while the mesial one (with single, gutter-shaped aperture in this case) is placed a certain distance below the hydrothecal base, so as to allow the formation of a rib composed of about 3-4 pairs of nematothecae arranged along its length; except for hydrothecae of the $1^{\text {st }}$ or $2^{\text {nd }}$ rib, those placed more distally in the corbula possess an extra, gutter-shaped nematotheca on their dorsal side (compare Fig. 11J and 11K). The gonothecae, lenticular in shape, are inserted at the bases of costae, close to the large internodal nematotheca; perisarc flimsy.

\section{Remarks}

The hydrothecae of $L$. fragilis sp. nov. are mainly characterized by the notable bulging (both abaxially and laterally) of their lower halves, recalling the thecae of $L$. brevirostris (Busk, 1852) and L. tridentata (Versluys, 1899). The former is equally present in the material dealt with herein (Fig. 11A) and is readily distinguished from the new species through its hydrothecae occupying the entire length of the cormidium, the lack of lateral swelling in their lower half, a mesial nematotheca provided with a single, gutter-shaped aperture as well as a hydrothecal rim bearing three pairs of large, triangular cusps, in addition to the median, abaxial one. Hydrothecae of $L$. tridentata share the same distinctive characters as those listed in L. brevirostris, but their rim is set with a pair of low, broad, triangular, lateral cusps, in addition to the median one (Migotto 1996).

As noted above in the description, the mesial nematotheca of $L$. fragilis sp. nov. has a wide apical aperture, partly camouflaged by a backwardly-rolled abaxial wall (Fig. 11I) that creates laterally two circular passages, giving the impression - upon a frontal view of the hydrotheca - that the nematotheca is bifid (Fig. 11H). Nematothecae having a similar aperture have been described in L. bathyalis Ryland \& Gibbons, 1991 (original account, Ryland \& Gibbons 1991: fig. 14d-e) but, in this species, the nematotheca is adnate to the entire length of the abaxial wall of the hydrotheca, leaving only a short portion free that surpasses the rim. Conversely, a true bifid mesial nematotheca is to be found in L. furcata (Vervoort, 1941) (original account Vervoort 1941). 


\section{Distribution}

Known only from its type locality, off New Caledonia (present study).
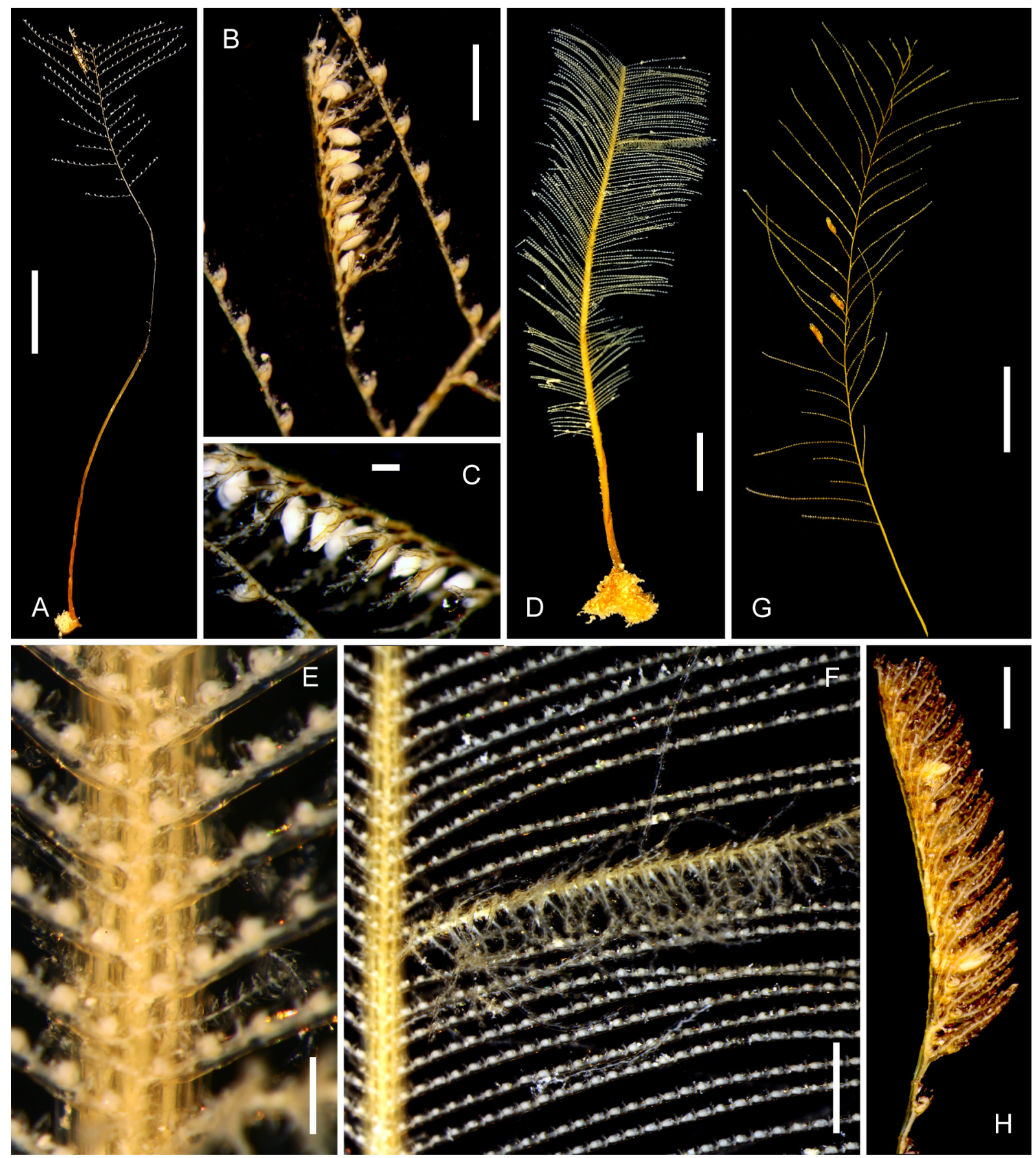

Fig. 12. A-C. Lytocarpia fragilis sp. nov, fertile colony (A) and details of a corbula (B-C), all from sample MNHN-IK-2015-523 (holotype). - D-F. Lytocarpia pilosa sp. nov., fertile colony (D), portion of stem, showing proximal parts of pseudophylactocarps (E), and corbula (F), all from sample MNHN-IK-2015-524 (holotype). - G-H. Lytocarpia pseudoctenata sp. nov., fertile colony (G) and corbula $(\mathrm{H})$, all from sample MNHN-IK-2015-527 (holotype). Scale bars: A, D = 1 cm; B, H = $1 \mathrm{~mm}$; $\mathrm{C}, \mathrm{E}=500 \mu \mathrm{m} ; \mathrm{F}=2 \mathrm{~mm} ; \mathrm{G}=2 \mathrm{~cm}$. 
Lytocarpia nigra (Nutting, 1905)

Fig. 13

Thecocarpus niger Nutting, 1905: 953, pl. 5 fig. 5, pl. 13 figs 1-6.

Thecocarpus niger - Stechow 1913: 96, figs 65-67. — Park 2010: 166, fig. 93.

Lytocarpia niger - Rho 1967: 346, fig. 7, pl. 1 fig. 1. - Xu et al. 2014: 493, fig. 365.

Lytocarpia nigra - Hirohito 1983: 77, fig. 40; 1995: 295, fig. 104c-e. — Schuchert 2015: 360, fig. 32.

Aglaophenia sp. - Inaba 1891: 307 (nr. 28), figs 82-85.

\section{Material examined}

PACIFIC OCEAN 11 colony, $8.5 \mathrm{~cm}$ high, fertile; off New Caledonia, stn CP4786; $22^{\circ} 46^{\prime} \mathrm{S}, 167^{\circ} 42^{\prime} \mathrm{E}$; 350-469 m; 29 Aug. 2016; KANACONO leg.; MNHN-IK-2015-509.

\section{Description}

Colony erect, with lightly fascicled stem irregularly branched, up to the $4^{\text {th }}$ order, so as to form an arborescent structure. Stem and branches divided into short internodes by means of transverse nodes. Proximal portion of branches devoid of cladia, but with a frontally-placed nematotheca on each internode. Subsequent internodes bearing alternate cladia, each accommodating a short apophysis and 3 nematothecae: one proximal, below the apophysis, one lateral next to it (axillar), and one conical at the base of the apophysis. Nematothecae on proximal internodes of side branches, as well as the inferior and axillar ones, inverted-triangular in general outline, basally adnate and rounded, distally free and there with a broad aperture with inwardly-curved adaxial wall, giving the impression that two lateral apertures are present. Conical nematotheca fairly developed, with rounded, apical aperture. Cladia close to one another, divided into short cormidia by means of transverse nodes, each cormidium comprising a hydrotheca and its 3 associated nematothecae: one mesial and a pair of laterals. Two intranodal septa are present: one basal, prolonged on opposite side into the hydrothecal lumen as a transverse to slightly upwardly-directed intrathecal septum, and one distal, at base of the lateral nematothecae. Mesial nematotheca arched, long, tubular, adnate for $2 / 3$ of its length, free part almost reaching the hydrothecal rim; a short, spout-like apical aperture, as well as an ovoid one near junction with abaxial hydrothecal wall. Lateral nematothecae rather short, merely surpassing the hydrothecal rim, with circular aperture apically, and large, ovoid foramen adaxially. Hydrothecal rim with 7 cusps: median, abaxial one with thickened perisarc forming a small triangular anterior projection, and 3 pairs of laterals. First cusp narrow and triangular, second (middle) cusp often split in middle, and third (posterior) wide and broadly rectangular. Terminal stolonization often present on tips of branches. Corbula open, up to $9 \mathrm{~mm}$ long, replacing normal cladium, composed proximally of a normal cormidium, followed by a short internode bearing a mesial nematotheca, and a succession of up to 70 internodes bearing alternate costae; nodes oblique. Costal internodes short, bearing an arched costa and 4 nematothecae: 3 on ventral (internal) side, and one dorsally (external). Ventral nematothecae: one at base of the costa, another one lateral to it (both elongated and with gutter-shaped apertures), as well as a short, conical nematotheca at the base of the insertion of costa. Dorsal nematotheca conical, with rounded apical aperture and a large, rounded, adaxial foramen. Gonothecae lenticular, with flimsy, transparent perisarc, borne on base of costa by means of short, indistinct pedicel. Gonophores not seen.

\section{Remarks}

As indicated by the specific name, living colonies of this species are characteristically dark colored, due to a black pigment found in the coenosarc. This, however, has been lost in the present alcohol-preserved specimen, but its morphological features match those described earlier (see synonymy). 


\section{Distribution}

Hawai'i, Japan, Korea (Schuchert 2015), China (Xu et al. 2014), New Caledonia (present study).

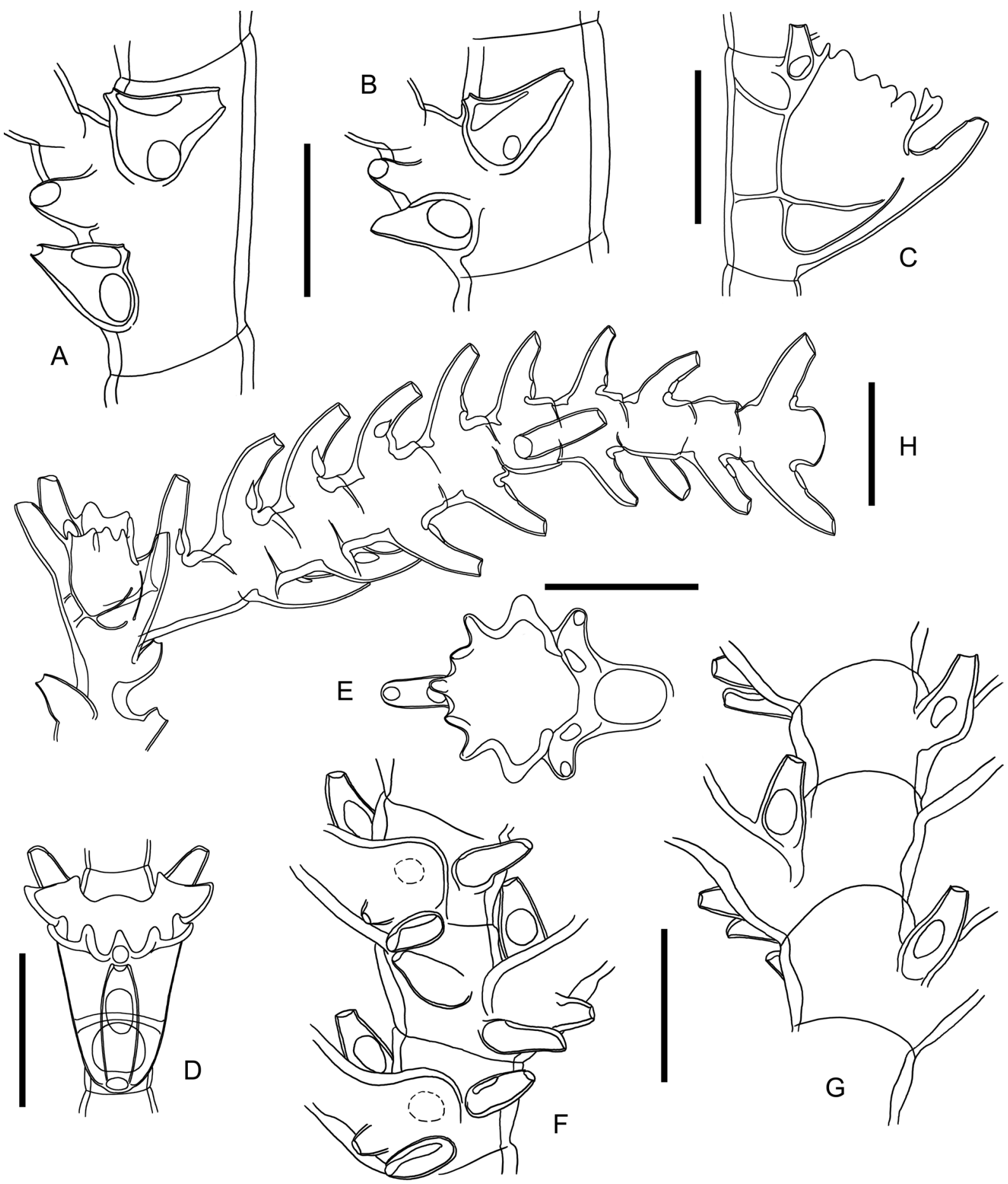

Fig. 13. Lytocarpia nigra (Nutting, 1905), from sample MNHN-IK-2015-509. A-B. Two stem internodes, to show variation in the shape of the frontal nematothecae. C-E. Hydrotheca in lateral (C), frontal (D) and apical (E) views. F-H. Rachis of corbula in frontal (F) and dorsal (G) aspects, and costa (H). Scale bars: $\mathrm{A}-\mathrm{H}=200 \mu \mathrm{m}$. 


\section{Lytocarpia pilosa sp. nov. urn:lsid:zoobank.org:act:D976AA1A-85C8-4F35-A03C-44118BDAF3B3}

Figs 12D-F, 14

\section{Diagnosis}

Lytocarpia forming robust, rigid, unbranched colonies with strongly fascicled stems. Division into internodes indistinct, but each module with a proximal, frontal nematotheca, a cladial apophysis with its conical nematotheca and a pseudophylactocarp, as well as a fronto-axillar nematotheca. Pseudophylactocarps composed of a long succession of internodes bearing a mesial and two lateral nematothecae. Cladia close to one another, composed of short internodes, each accommodating a strongly S-shaped hydrotheca and its 3 gutter-shaped nematothecae; mesial one half adnate, projecting obliquely upwards, overtopping hydrothecal rim; the latter with strong median triangular cusp and 3 lateral pairs of wider and lower cusps. Corbulae on modified cladia, after a sequence of two normal cormidia; rachis geniculate, repetitive units with a costa and a spout-like nematotheca lateral to it; each costa with a proximal nematotheca, a hydrotheca with a posterior nematotheca and a downwardlydisplaced mesial nematotheca, so as to give rise to a sequence of internodes, each with a complement of 3 nematothecae. Gonothecae lenticular, flimsy, inserted at the base of costae.

\section{Etymology}

From the Latin 'pulosus, -a, -um', meaning 'hairy', with reference to the hirsute aspect of its colonies, due to the profuse occurrence of pseudophylactocarps.

\section{Material examined}

\section{Holotype}

PACIFIC OCEAN 1 colony devoid of its distal part, $9 \mathrm{~cm}$ high, fertile; off New Caledonia, stn CP4675; $22^{\circ} 50^{\prime} \mathrm{S}, 167^{\circ} 30^{\prime} \mathrm{E}$; 350-366 m; 13 Aug. 2016; KANACONO leg.; MNHN-IK-2015-524.

\section{Description}

Colony erect, of strongly-built appearance, comprising a single plume arising from a well-developed, much branched hydrorhizal mass. Stem unbranched, strongly fascicled, proximal part $(2.5 \mathrm{~cm}$ long $)$ devoid of hydrocladia, and provided with two deeply-incised, oblique nodes passing through all (main and accessory) tubes at a time. Main tube with thick perisarc, without evident division into internodes, but comprising a regular succession of modules composed of a proximal, frontal nematotheca, a lateral apophysis supporting a cladium, bearing a conical nematotheca (with small, rounded, apical aperture) near its base, as well as a fronto-axillar nematotheca; stem nematothecae large, saccate, adnate for more than half their length, adaxial wall strongly emarginated. Exceedingly long and lax pseudophylactocarps are regularly given off from the cladial apophyses, projecting onto the side opposite to corresponding cladium, freely rippling with the water currents; pseudophylactocarps composed of a succession of elongated (390-405 $\mu \mathrm{m}$ long) internodes comprising triplets of nematothecae, one proximal and mesial in position, and two other distal and laterally-displaced; proximalmost internode comparatively shorter, retaining only its mesial nematotheca. Cladia close to one another, arched backwards, up to $1.8 \mathrm{~cm}$ long, divided into relatively short $(385-435 \mu \mathrm{m})$ internodes by means of transverse nodes, each internode accommodating a hydrotheca with its three associated nematothecae (all gutter-shaped): one mesial and a pair of laterals. Hydrotheca strongly S-shaped, with an internal septum given off from the proximal portion of its adaxial wall, the end of which reaches almost the middle of the lumen; mesial nematotheca about half adnate, projecting out- and upwards, and overtopping the hydrothecal margin; aperture 180 $185 \mu \mathrm{m}$ wide, rim provided with a prominent, rounded, central, abaxial cusp, followed laterally by 3 pairs of low, wide, rather inconspicuous, triangular cusps; lateral nematothecae almost tubular, strongly projecting forwards and slightly upwards. Corbulae on highly modified hydrocladia, arising after a couple of normal cormidia; corbula up to $17 \mathrm{~mm}$ long, open, tubular, rachis decidedly geniculate, not divided into distinct internodes; each equivalent of internode with a costa and a spout-shaped nematotheca lateral 
to it; up to 34 costae per side of gonotheca; costa composed of a proximal, short, tubular part provided with a nematotheca, followed by a hydrotheca whose mesial nematotheca was displaced far below its base, so as to accommodate the insertion of a succession of highly modified hydrothecae not retaining their cavities, but represented only by their respective nematothecae; basal hydrotheca provided with an additional, posterior nematotheca; first modified hydrotheca in the row comparatively longer than the

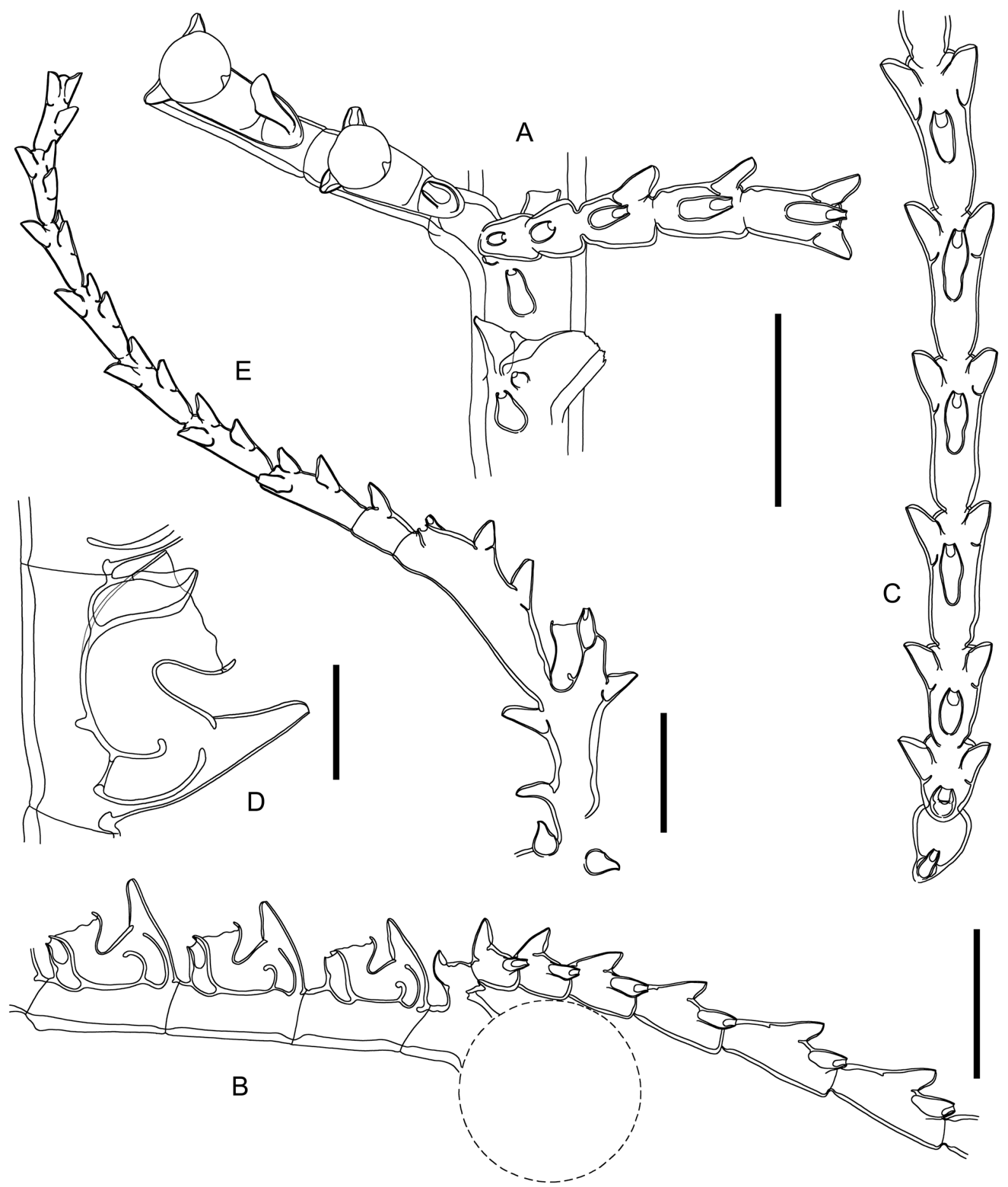

Fig. 14. Lytocarpia pilosa sp. nov., from sample MNHN-IK-2015-524. A-C. Portion of stem seen frontally (A) and basally (B), and detached pseudophylactocarp (C). D. Hydrotheca. E. Costa of corbula. Scale bars: A-C, $E=500 \mu \mathrm{m} ; \mathrm{D}=200 \mu \mathrm{m}$. 
subsequent ones, and provided with two mesial nematothecae; all nematothecae on costa spout-shaped. Gonothecae lenticular, with flimsy perisarc, insert near the base of each costa.

\section{Remarks}

Hydrothecae of L. pilosa sp. nov. are morphologically similar to those of L. brevirostris (Busk, 1852) and $L$. tridentata with respect to their sigmoid shape in lateral view. However, in none of these the hydrothecae are produced abaxially (in their lower halves) to a similar extent, and their apertures are less tilted frontally. In addition, the new species is a much more robust hydroid, with a thick and strongly fascicled stem, with longer and densely-set cladia, and with profuse, defensive structures, the pseudophylactocarps.

Among its congeners, pseudophylactocarps were documented so far in L. angulosa (Lamarck, 1816) but, in this species, they replace normal hydrocladia (Billard 1913: fig. 73). Such structures also occur in the genus Taxella Allman, 1874 but, there, the $2-3$ proximalmost internodes are represented by normal cormidia, while the remainder of the hydrocladium is modified so as to include only nematothecate internodes (e.g., T. longicornis (Busk, 1852) [Watson 2000: fig. 48e; Ronowicz et al. 2017: fig. 11d], T. hornelli (Thornely, 1904) [Thornely 1904: pl. 3 fig. 1a; Ronowicz et al. 2017: fig. 10c-d]). The new species Macrorhynchia spiralis sp. nov., described below, equally bears pseudophylactocarps, although their number per colony is far from significant.

\section{Distribution}

Known only from the type locality, off New Caledonia (present study).

Lytocarpia pseudoctenata sp. nov. urn:1sid:zoobank.org:act:F9BD38C7-AFF6-4703-B6E4-3C11BB0EFE16

Figs $12 \mathrm{G}-\mathrm{H}, 15$

\section{Diagnosis}

Species of Lytocarpia with tall, slender, pinnate colonies of delicate appearance. Stems unbranched, slightly fascicled, with long internodes provided with a frontal row of 4-10 nematothecae, a lateral apophysis supporting a cladium and its conical nematotheca, as well as with a fronto-axillar nematotheca. Cladia fairly distant from one another, shifted on to the anterior side of the colony. Cormidia short, with up to 7 intranodal ridges; hydrothecae strongly S-shaped, with ad- and abaxial ridges projecting far into their lumina; mesial nematotheca adnate for $3 / 4$ its length, free part projecting upwards, not reaching hydrothecal margin; the latter with strong, median, abaxial cusps and edges with 3 pairs of additional cusps, the $2^{\text {nd }}$ being comparatively more developed. Corbula on distal end of a hydrocladium, after a sequence of 5-18 normal cormidia; rachis geniculate, segments with a costal apophysis and a nematotheca lateral to it; costae forked, with a hydrotheca (devoid of its lateral nematothecae) in middle and appendages with successive pairs of opposite to subopposite nematothecae; gonothecae lenticular, flimsy, arising from the base of costal apophyses.

\section{Etymology}

The specific name indicates obvious resemblances with Aglaophenia ctenata (Totton, 1930).

\section{Material examined}

Holotype

PACIFIC OCEAN -1 colony, ca $14 \mathrm{~cm}$ high, hydrorhiza missing, bearing 3 corbulae; off New

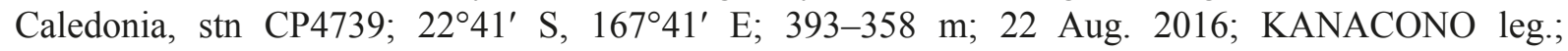
MNHN-IK-2015-527. 


\section{Paratype}

PACIFIC OCEAN - 1 colony fragment, $2.2 \mathrm{~cm}$ long, with one gonotheca in middle part; off New Caledonia, stn DR4772; 2302' S, 168 21' E; 795-230 m; 28 Aug. 2016; KANACONO leg.; MNHN-IK-2015-528.

\section{Description}

Undamaged colonies reaching more than $14 \mathrm{~cm}$ high; erect, slender and of delicate appearance, unable to support themselves when out of liquid, though perisarc rather thick throughout the colony; hydrorhiza not seen; stems lightly fascicled, composed of several superimposed auxiliary tubes, each adhering to the dorsal side of the preceding one, not forming a beam around the main tube, but rather resulting in a laterally-flattened structure; a notable deeply-cut, oblique node some distance above the origin from hydrorhiza, passing through all cauline tubes at a time; occasional oblique nodes sporadically along the remainder of stem; division into additional internodes not always distinct, though transverse nodes (170-180 $\mu \mathrm{m}$ wide) are more noticeable in the younger parts of the stem, where the perisarc is thinner; each internode 2-4 mm long, comprising a frontal row of 4-10 saccate nematothecae (with gutter-shaped, adaxial apertures), a short (ca $60 \mu \mathrm{m}$ ) cladial apophysis above carrying basally a conical nematotheca (with small, rounded, apical aperture), as well as an elbow nematotheca (also with guttershaped aperture) lateral to the insertion of apophysis on the internode (fronto-axillar). Basalmost cladia broken off, but arrangement alternate along the longest portion of the stem; up to $3.7 \mathrm{~cm}$ long, the two rows shifted on to the anterior side of the colony so as to form an acute angle; cladia fairly distant from one another in each row; divided into rather short $(585-600 \mu \mathrm{m})$ internodes by means of transverse nodes (145-150 $\mu \mathrm{m}$ wide), each comprising a hydrotheca and its three associated nematothecae: one mesial and a pair of laterals; hydrotheca 525-540 $\mu \mathrm{m}$ deep, strongly S-shaped, with 2 internal septa, one adaxial arising a short distance above the base, and one abaxial given off a certain distance below the aperture from the abaxial wall, both septa protruding at least into the middle of the hydrothecal lumen; internodes with a number of incomplete internal septa: 2 abaxial and up to 5 on their adaxial side; mesial nematotheca long, tubular, adnate for more than $3 / 4$ its length, leaving only a short $(100-115 \mu \mathrm{m})$ portion free, provided with a gutter-shaped aperture along its whole free length; lateral nematothecae tubular, 215-220 $\mu \mathrm{m}$ long, aperture with rim deeply-scooped adaxially; hydrothecal margin with a prominent, rounded, abaxial cusp, continued on each side by three broad, triangular cusps, the second being the most developed. Gonosome an open corbula borne on a hydrocladium after a sequence of 5-18 normal cormidia; rachis slightly geniculate, divided into very short internodes (by means of transverse nodes), each bearing a costal apophysis and an elbow nematotheca lateral to it; costa separated from apophysis by transverse node; costa forked, with a basal hydrotheca (lateral nematothecae lost) in middle; mesial nematotheca situated far below the hydrothecal base, so as to accommodate the insertion of the 'anterior' arm, comprising 5-6 pairs of opposite to subopposite nematothecae; a nematotheca on the back of the hydrotheca, above which is inserted the 'posterior' arm, comprising 7-8 opposite to subopposite nematothecae; proximalmost costa of a corbula with the mesial nematotheca immediately below the hydrothecal base, not giving rise to the "anterior" arm set with nematothecae; all nematothecae elongated, with deeply-scooped adaxial margins. Gonothecae lenticular, with flimsy perisarc, arising from the base of the costal apophyses.

\section{Remarks}

None of the nominal species of Lytocarpia described so far (Schuchert 2019) possesses simultaneously two (ab- and adaxial) strongly-developed internal septa, creating such a distinctive, S-shaped appearance of their hydrothecae, as L. pseudoctenata sp. nov.

The new species shows striking resemblances with Aglaophenia ctenata (Totton, 1930) with respect to the morphology of both hydrothecae and some components of the gonosome. Indeed, hydrothecae of both are borne on short internodes, are strongly S-shaped and possess two intrathecal ridges, one 
abaxial, the other adaxial, projecting halfway across their lumina (compare Fig. 15B with Totton (1930: fig. 69a)). However, the hydrothecal apertures of A. ctenata appear more tilted forward (Totton 1930: fig. 69a; Ralph 1961: fig. 9b; Vervoort \& Watson 2003: fig. 62e, g-i). Although both species possess similarly long cladia, those of $A$. ctenata are 'tightly packed' (compare image 'a' from the frontispiece of Vervoort \& Watson (2003) with Fig. 12G herein). Its stem internodes possess "one terminal apophysis with a pair of opposite nematothecae at their base and one or two nematothecae on the proximal part
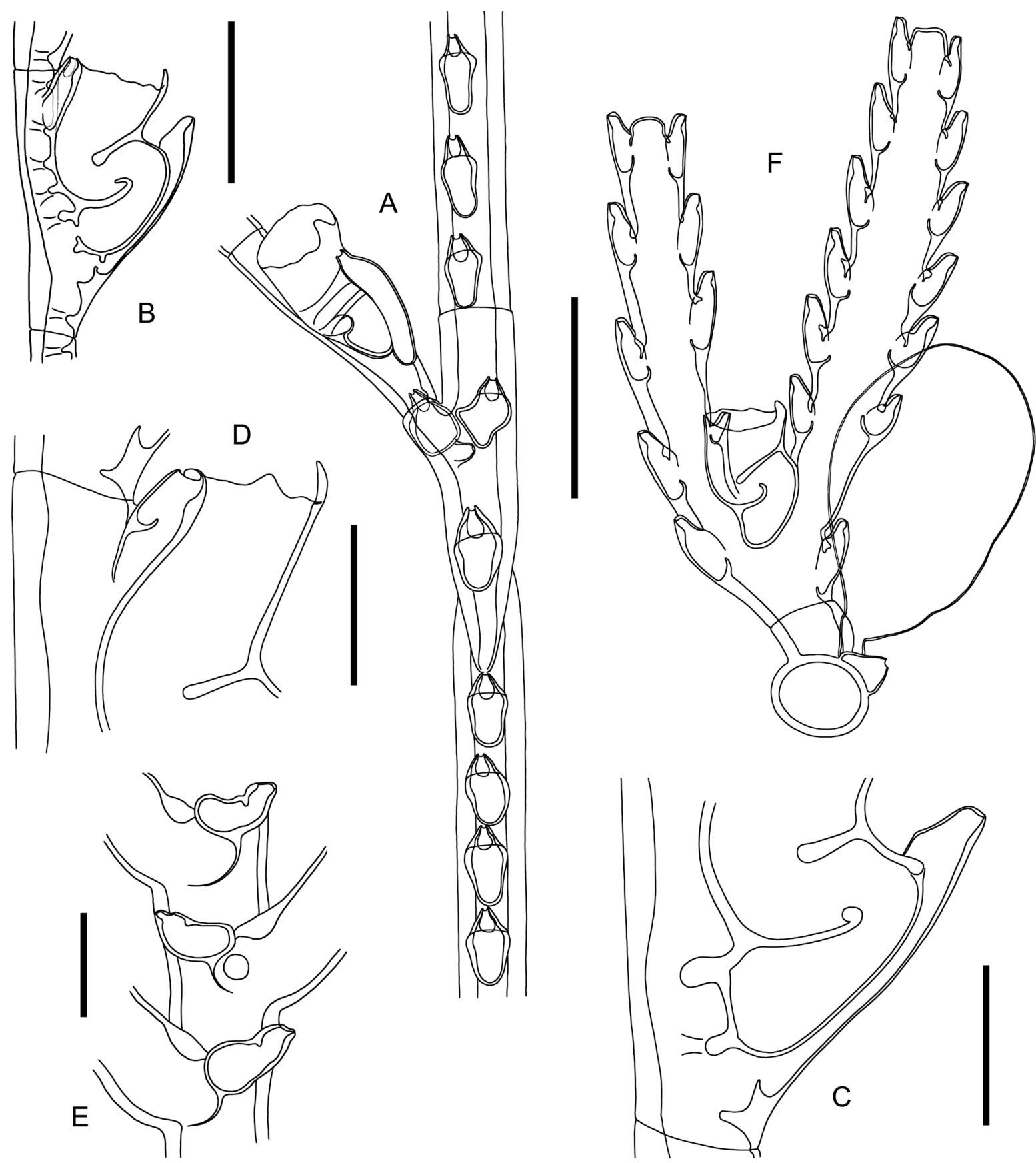

Fig. 15. Lytocarpia pseudoctenata sp. nov. A. Portion of stem. B-D. Hydrotheca (B) and details of its basal (C) and distal (D) parts, all seen laterally. E-F. Portion of the rachis of corbula, and costa with gonotheca (F). From samples MNHN-IK-2015-527 (C-D) and MNHN-IK-2015-528 (A-B, E-F). Scale bars: $\mathrm{A}, \mathrm{F}=500 \mu \mathrm{m} ; \mathrm{B}-\mathrm{E}=200 \mu \mathrm{m}$. 
[...]. No mamelon has been observed [...]" (Vervoort \& Watson 2003). As with the gonohydrocladium of L. pseudoctenata sp. nov., that of A. ctenata also appears bifid (Vervoort \& Watson 2003: fig. 62j), but there is no hydrotheca associated with it, and the number and position of the nematothecae are also slightly different.

\section{Distribution}

Known only from off New Caledonia (present study).

Lytocarpia cf. spiralis (Totton, 1930)

Figs $16 \mathrm{~A}, 17 \mathrm{~A}-\mathrm{B}$

Thecocarpus spiralis Totton, 1930: 238, fig. 69c-d.

Thecocarpus spiralis - Ralph 1961: 59, figs 8i-j, 10d.

Lytocarpia spiralis - Vervoort \& Watson 2003: 321, figs 77d-h, 78a-e.

\section{Material examined}

PACIFIC OCEAN 11 colony, ca $46 \mathrm{~cm}$ high, bearing 11 plumose side branches, without gonothecae, hydrothecae with mostly damaged rims; off New Caledonia, stn DW5038; $19^{\circ} 55^{\prime} \mathrm{S}, 158^{\circ} 35^{\prime} \mathrm{E} ; 340 \mathrm{~m}$; 22 Sep. 2017; KANADEEP leg.; MNHN-IK-2015-546.

\section{Remarks}

The present material agrees well with descriptions of Lytocarpia spiralis (Totton, 1930) by Ralph (1961) and Vervoort \& Watson (2003) but, since it is devoid of its gonosome and the condition of the hydrothecal rim could not be assessed properly, it is assigned with a query to it.

\section{Distribution}

Previously known from waters around New Zealand (Vervoort \& Watson 2003); New Caledonia (present study).

Lytocarpia subtilis sp. nov. urn:1sid:zoobank.org:act:F077EEF0-D13A-499A-AA86-6F8D82062D42

Figs $16 \mathrm{~B}, 17 \mathrm{C}-\mathrm{J}$

\section{Diagnosis}

Species of Lytocarpia with tall, exceedingly slender, pinnate colonies of a very delicate appearance, with lightly fascicled, unbranched stems. Division into internodes indistinct; a row of 8-17 frontal nematothecae between two successive cladial apophyses, the latter with a basal, simple, conical nematotheca, and a fronto-axillar nematotheca. Cladia widely-spaced from one another; cormidia quite long, with up to 11 intranodal septa, accommodating an elongate hydrotheca and its 3 associated nematothecae; free part of mesial nematotheca gutter shaped, borne on a prominent, basal, abaxial bulge of the hydrotheca; an adaxial, intrathecal septum projecting slightly upwards and over halfway into the hydrothecal lumen; rim with prominent, median, abaxial cusps, edges wavy. Corbula on distal end of cladium; rachis indistinctly divided; each segment with a lateral costa and a nematotheca near to its insertion point; costae with a hydrotheca with its full complement of nematothecae, as well as an additional one on dorsal side of internode; mesial nematotheca far below hydrothecal base, so as to give rise to an appendage set with lateral nematothecae. 


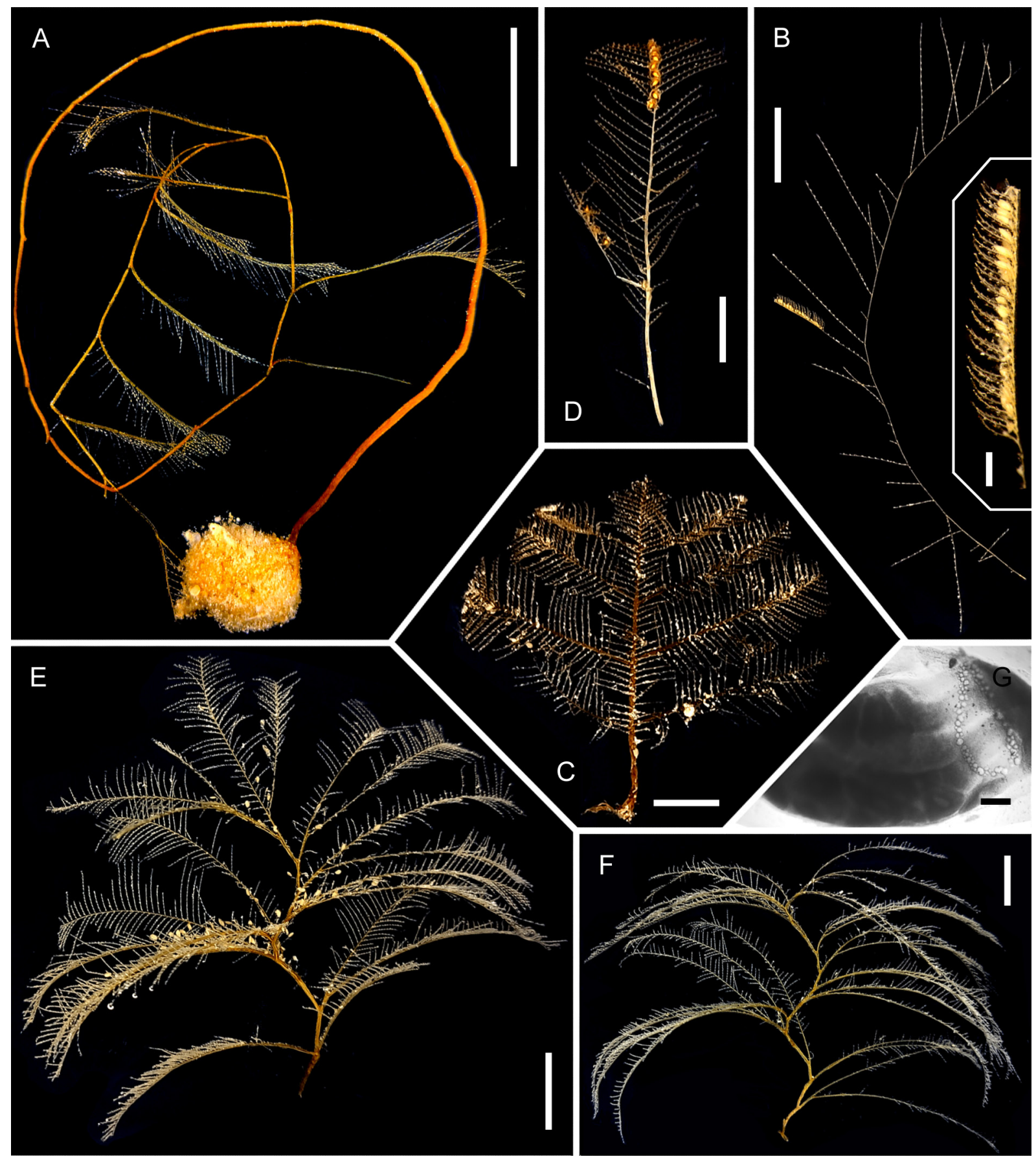

Fig. 16. A. Lytocarpia cf. spiralis (Totton, 1930), colony from sample MNHN-IK-2015-546. B. Lytocarpia subtilis sp. nov., colony and corbula (insert) from sample MNHN-IK-2015-525 (holotype). - C-D. Macrorhynchia phoenicea (Busk, 1852) (C), from sample MNHN-IK-2015-512, compared to M. disjuncta (Pictet, 1893) (D), from sample MNHN-IK-2015-513. - E-G. Macrorhynchia spiralis sp. nov., colonies from samples MNHN-IK-2015-519 (E, holotype) and MNHN-IK-2015-520 (F, one paratype), and medusoid gonophore $(\mathrm{G})$ from former sample. Scale bars: $A=3 \mathrm{~cm}$; $B-F=1 \mathrm{~cm}$; $\mathrm{B}$ (insert) $=1 \mathrm{~mm} ; \mathrm{G}=100 \mu \mathrm{m}$. 


\section{Etymology}

From the Latin 'subtilis', meaning 'slender', to describe the appearance of its hydrothecae.

\section{Material examined}

\section{Holotype}

PACIFIC OCEAN - 1 upper part of colony, ca $8.5 \mathrm{~cm}$ long, bearing a corbula; off New Caledonia, stn DW4711; 2247' S, 167²4' E; 335-338 m; 18 Aug. 2016; KANACONO leg.; MNHN-IK-2015-525.

\section{Paratype}

PACIFIC OCEAN -3 specimens ( 1 colony, nearly complete, ca $14.5 \mathrm{~cm}$ high, with hydrorhiza but missing its distalmost part, without gonosome, 1 colony fragment, ca $14.5 \mathrm{~cm}$ long, missing both hydrorhiza and distal part, without gonosome, and 1 colony fragment, ca $5.5 \mathrm{~cm}$ long, missing both its hydrorhiza and distal part, bearing a corbula); off New Caledonia, stn CP4674; 22 ${ }^{\circ} 48^{\prime} \mathrm{S}, 1^{\circ} 7^{\circ} 29^{\prime} \mathrm{E}$; 311-302; 13 Aug. 2016; KANACONO leg.; MNHN-IK-2015-526.

\section{Description}

Colony erect, unable to support itself outside liquid, exceedingly slender and delicate; arising from branched, rhizoid stolon anchoring it in sandy bottom. Stem unbranched, lightly fascicled proximally, monosiphonic for most of its length; a deeply-cut, oblique node a certain distance above its origin from hydrorhiza; below the node, a succession of large, saccate nematothecae in a row along the main tube; above the node, the stem bears widely-spaced (2.5-3 $\mathrm{mm}$ apart), alternate cladia, the latter borne on short (ca $70 \mu \mathrm{m}$ ) apophyses given off laterally and towards the 'front' of the colony, the two rows of cladia forming an acute angle; division into internodes (nodes transverse, 160-170 $\mu \mathrm{m}$ wide) inconspicuous on stem, but equivalents of internodes comprising a row of 8-17 frontal, saccate nematothecae, a lateral apophysis above them, a simple, conical nematotheca (with small, rounded, apical aperture) on the basal part of the apophysis, as well as fronto-axillar nematotheca, rather lateral to the apophysis, having the distal part shifted on to the opposite direction; all stem nematothecae, except that borne on the mamelon, with large, adaxial, gutter-shaped apertures. Cladia up to $1.8 \mathrm{~cm}$ long, composed of up to 21 cormidia, not distinctly demarcated by transverse nodes; each cormidium 810-860 $\mu \mathrm{m}$ long, $100-105 \mu \mathrm{m}$ wide at node, with a hydrotheca placed some distance after its proximal node, and three associated nematothecae: one mesial and a pair of laterals; $10-11$ internodal projections of the perisarc, all but two given off from the adaxial wall of the hydrotheca; hydrothecae exceedingly long $(680-705 \mu \mathrm{m})$, slightly conical, with a basal abaxial bulge, on the top of which is mounted the free portion of the mesial nematotheca; the latter long, cylindrical, slightly concave in general outline, adnate for about $2 / 3$ of its length, free part $120-130 \mu \mathrm{m}$ long, with gutter-shaped aperture all the way down to the junction with the lower abaxial wall of hydrotheca, apical rim distinctly crenulated; lateral nematothecae moderately long $(170-175 \mu \mathrm{m})$, broadly tubular, reaching the hydrothecal margin, aperture scooped out on adaxial side, abaxial rim distinctly crenulated; hydrothecal aperture 225-235 $\mu \mathrm{m}$ wide, rim with a prominent abaxial cusp with crenulated apex, ridges rather wavy, without distinct cusps; an internal septum is given off from the lower part of the adaxial wall of the theca and projects for $2 / 3$ into the lumen. Gonosome an open corbula borne on distal ends of cladia, after a succession of 6-10 normal cormidia; corbula up to $8 \mathrm{~mm}$ long, tubular, with straight rachis, not distinctly divided into internodes; segments short, with an indistinct lateral apophysis bearing a costa and a saccate nematotheca (with gutter-shaped aperture) lateral to it; gonothecae lenticular, with flimsy perisarc, borne near the insertion of the costa on the rachis; costae up to 20-21 per side of the gonotheca, comprising a hydrotheca with a complete set of nematothecae, in addition to which there is an extra nematotheca on the dorsal side of the internode; mesial nematotheca far below the hydrothecal base, leaving room for the insertion of a long appendage carrying 7-11 variously arranged nematothecae on both sides. 


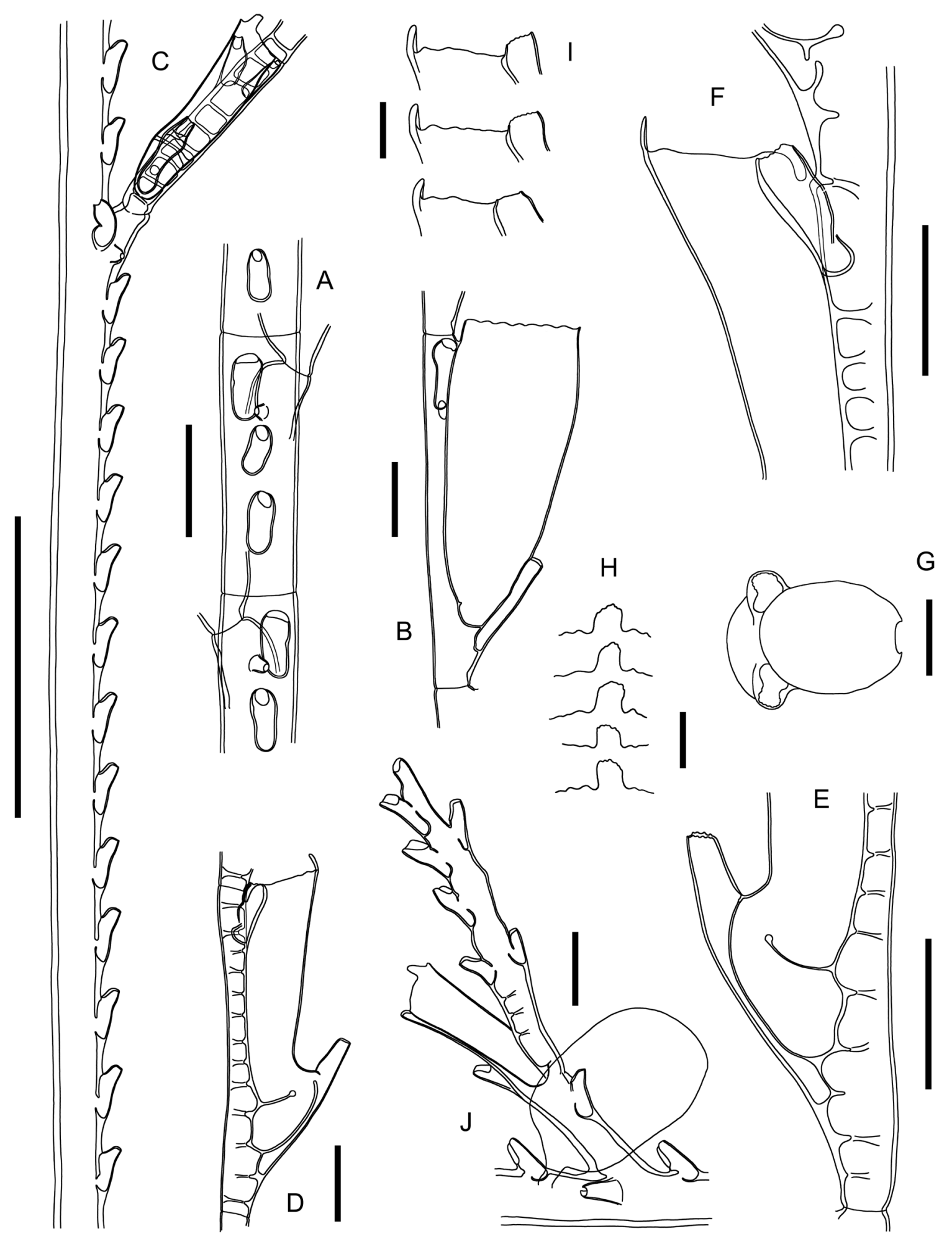

Fig. 17. A-B. Lytocarpia cf. spiralis (Totton, 1930), portion of stem (A) and hydrotheca (B), from sample MNHN-IK-2015-546. - C-J. Lytocarpia subtilis sp. nov. C. Portion of stem. D-I. Lateral view of a hydrotheca (D), with details of its basal (E) and distal (F) parts; hydrotheca seen apically (G), and variation in the shape of its margin seen frontally $(\mathrm{H})$ and laterally $(\mathrm{I})$. J. Portion of corbula rachis with costa and gonotheca. From samples MNHN-IK-2015-525 (C, E-G) and MNHN-IK-2015-526 (D, H-J). Scale bars: A $=300 \mu \mathrm{m}$; B, D-F, $\mathrm{J}=200 \mu \mathrm{m} ; \mathrm{C}=1 \mathrm{~mm}$; G-I $=100 \mu \mathrm{m}$. 


\section{Remarks}

None of the nominal species of Lytocarpia Kirchenpauer, 1872 described so far (Schuchert 2019) possesses such exceedingly long and slender hydrothecae. Elongate, but not slender, hydrothecae are met with in L. alata Vervoort \& Watson, 2003 (original account), L. distans Allman, 1877 (Ramil \& Vervoort 1992b), M. myriophyllum (Linnaeus, 1758) (Ramil et al. 1998), and L. spiralis (Totton, 1930) (dealt with in the present study, Fig. 17B).

\section{Distribution}

Known only from off New Caledonia (present study).

Genus Macrorhynchia Kirchenpauer, 1872

Macrorhynchia phoenicea (Busk, 1852)

Figs $16 \mathrm{C}-\mathrm{D}, 18 \mathrm{~A}$

Macrorhynchia phoenicea - Di Camillo et al. 2009: 218, figs 2h-i, 6, 9.

\section{Material examined}

PACIFIC OCEAN 1 profuse colony on gorgonian, with stems up to $10 \mathrm{~cm}$ high, some bearing

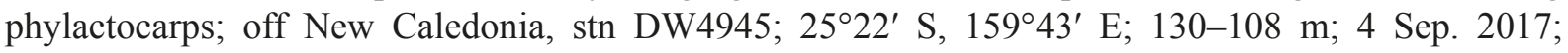
KANADEEP leg.; MNHN-IK-2015-510 1 colony, composed of a couple of stems, 2.5 and $4 \mathrm{~cm}$

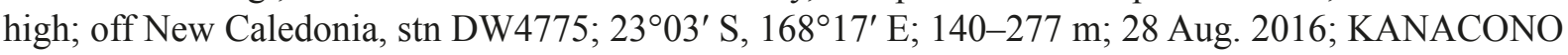
leg.; MNHN-IK-2015-511 5 colonies, 2.5-3.5 cm high, of which 4 bear incipient phylactocarps; off New Caledonia, stn DW4774; 2301' S, 168¹9' E; 100-90 m; 28 Aug. 2016; KANACONO leg.; MNHN-IK-2015-512.

\section{Comparative material}

PACIFIC OCEAN 11 complete colony, $6.5 \mathrm{~cm}$ high, as well as 3 fragments $(1.5,2.5$ and $3.5 \mathrm{~cm}$ long) of Macrorhynchia disjuncta (Pictet, 1893), all fertile; off Vanuatu, stn CP1104; 1504' S, $167^{\circ} 07^{\prime} \mathrm{E}$; 125-129 m; 7 Oct 1994; MUSORSTOM 8 leg.; MNHN-IK-2015-513.

\section{Remarks}

For a recent description of this well-known species, refer to Di Camillo et al. (2009), who also provide an extensive synonymy.

Schuchert (2003) noted striking resemblances between the hydrothecae of Aglaophenia disjuncta Pictet, 1893, a hydroid with a so far unknown gonosome, and those of the present species, and questioned their possible conspecificity. A few well-preserved, fertile specimens, undoubtedly assignable to Pictet's species, occur in material from off Vanuatu gathered during the MUSORSTOM 8 Expedition. Their appearance (Fig. 16D) immediately distinguishes them from typical colonies of M. phoenicea (Fig. 16C), in being more delicate, with a less rigid and straw-colored perisarc, with more distant and comparatively longer cladia, with longer cormidia and slightly larger hydrothecae.

Stems of the species described by Pictet (1893) are lightly fascicled and scarcely branched, as for instance with one branch occurring in the tallest $(6.5 \mathrm{~cm}$ high) specimen available. The stem and side branches are transversely divided into moderately long internodes, each bearing a cladial apophysis and 3 nematothecae, two large and one reduced: one at the base of the apophysis, a second axillar, and a short, conical theca on a mamelon (Fig. 18B). The large nematothecae are half adnate to the internode and possess a small, rounded aperture projecting laterally, as well as a large, broadly ovoid 
aperture behind. The proximal parts of the stem and branches are devoid of cladia, bear a row of large nematothecae with a conical distal half and have one of their apertures pointing upwards, while the other is comparatively larger and situated behind. The characteristic shape of the hydrothecae is depicted in Fig. 18C. The gonosome is typical of Macrorhynchia, and replaces a normal cladium, not forming pseudo-corbulae, but isolated phylactocarps; the proximalmost internode is a normal cormidium, on the distal part of which is inserted a long appendage with pinnate appearance resuting from the presence of (often) opposite pairs of exceedingly long nematothecae with two apertures: one small, apical, the other ovoid, at the base of the nematotheca. Occasionally, a few additional nematothecae in a row are to be found on the outer side of the phylactocarp. The gonothecae are large and lenticular, with flimsy perisarc, and are borne near the base of the appendage, amongst the proximalmost nematothecae.

\section{Distribution}

Widespread in the tropical parts of the Indian and southern Pacific oceans (Di Camillo et al. 2009).

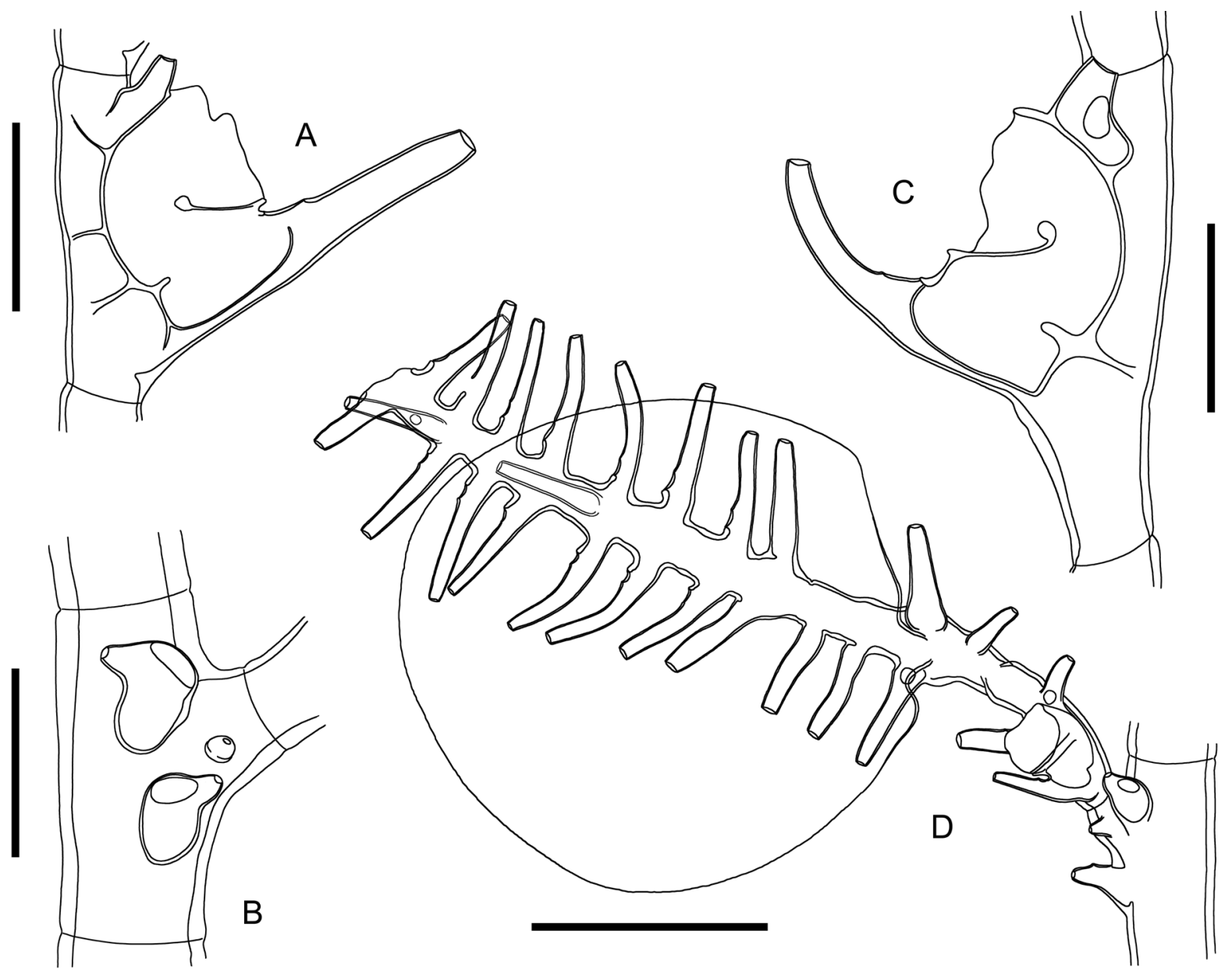

Fig. 18. A. Macrorhynchia phoenicea (Busk, 1852), hydrotheca from sample MNHN-IK-2015-510. B-D. Macrorhynchia disjuncta (Pictet, 1893), portion of stem (B), hydrotheca (C) and phylactocarp with gonotheca (D) from sample MNHN-IK-2015-513. Scale bars: A-C $=200 \mu \mathrm{m} ; \mathrm{D}=500 \mu \mathrm{m}$. 


\section{Macrorhynchia spiralis sp. nov. urn:lsid:zoobank.org:act:DA1E42B9-C682-4639-B3B1-4A9A7E2C7143}

Figs $16 \mathrm{E}-\mathrm{G}, 19$; Table 3

\section{Diagnosis}

Species of Macrorhynchia with a distinctly spirally-twisted stem, giving rise at each bend to a side branch that branches soon again, forming a bifid ramification. Stem and side branches strongly fascicled. Internodes short, with a proximal frontal nematotheca, a cladial apophysis above with its simple, conical nematotheca and a fronto-axillar nematotheca; cauline nematothecae saccate, with deeply scooped adaxial walls. Cladia alternate, fairly close to one another; cormidia moderately long, hydrotheca cupshaped, rather deep, aperture slightly sloping frontally, rim with 9 triangular cusps with rounded tips, of which the median, abaxial one is the most prominent; a slightly sigmoid, adaxial, intrathecal septum given off softly obliquely, reaching almost to abaxial wall; mesial nematotheca with short, spoutlike aperture, not reaching middle level of hydrotheca; lateral nematothecae barrel-shaped, with rim scooped out adaxially. Pseudophylactocarps, composed of chains of atrophied hydrothecae, borne on proximal parts of branches. Phylactocarp borne on a modified cladium, after 1-2 normal cormidia; first (occasionally second) segment, an atrophied hydrotheca, with its mesial nematotheca displaced more distally, and a short, lateral projection (on one side) bearing a couple of nematothecae similar to the laterals; gonotheca lenticular, flimsy, on top of atrophied hydrotheca, between the lateral nematothecae; gonophore, a medusoid.

\section{Etymology}

From the Latin 'spira', meaning 'spiral', with reference to the distinctive shape of the stem.

\section{Material examined}

Holotype

PACIFIC OCEAN - upper part of 1 colony, ca $6.5 \mathrm{~cm}$ high, with female gonophores; off New Caledonia, stn DW4954; 2412' S, 15941' E; 300 m; 5 Sep. 2017; KANADEEP leg.; MNHN-IK-2015-519.

\section{Paratypes}

PACIFIC OCEAN - upper part of 1 colony, ca $8 \mathrm{~cm}$ high, with gonophores; off New Caledonia, stn

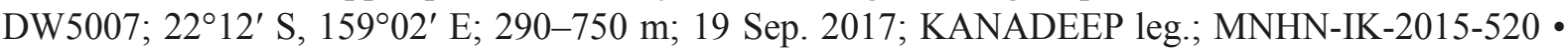
1 entire sterile colony, ca $10.5 \mathrm{~cm}$ high; off New Caledonia, stn DW5008; $22^{\circ} 12^{\prime} \mathrm{S}, 159^{\circ} 02^{\prime} \mathrm{E}$; 300-750 m; 19 Sep. 2017; KANADEEP leg.; MNHN-IK-2015-522.

\section{Description}

Colonies erect, sympodially built, with fascicled stems and side branches, grading to monosiphonic distally. Stem straight basally for a varied length, then bends at irregular intervals adopting a spiral arrangement. At each bend, a side branch arises as a rectilinear prolongation of the preceding portion of the stem, and usually ramifies once a short distance from its origin, both branches bearing hydrocladia for most of their length; proximally, a linear succession of saccate nematothecae with large apical foramina. Division into internodes indistinct wherever the perisarc is thick, but becomes evident towards the distal parts of the branches; internodes relatively short (400-420 $\mu \mathrm{m}$ long, 245-250 $\mu \mathrm{m}$ wide at node), with a large, proximal nematotheca, a cladial apophysis above, a fronto-axillar nematotheca, and a simple, conical nematotheca (with small, rounded, apical aperture) on the basal part of apophysis; nematothecae saccate, adnate for most of their length, having apically a large aperture whose rim is lowered adaxially. Cladia alternate, up to $14 \mathrm{~mm}$ long, composed of short cormidia (475-490 $\mu \mathrm{m}$ long, 95-100 $\mu \mathrm{m}$ wide at node), each accommodating a hydrotheca and its three nematothecae: one mesial and a pair of laterals. Hydrotheca cup-shaped, rather deep (390-400 $\mu \mathrm{m})$, abaxial wall 215-240 $\mu \mathrm{m}$ long, straight for most of 
its length, gently expanding towards aperture; the latter 205-215 $\mu \mathrm{m}$ wide, slightly sloping frontally; rim with 9 rounded cusps, the uneven, abaxial one being the most prominent, and slightly inwardlycurved, the 4 pairs on the edges being comparatively broader and of varied development; an internal
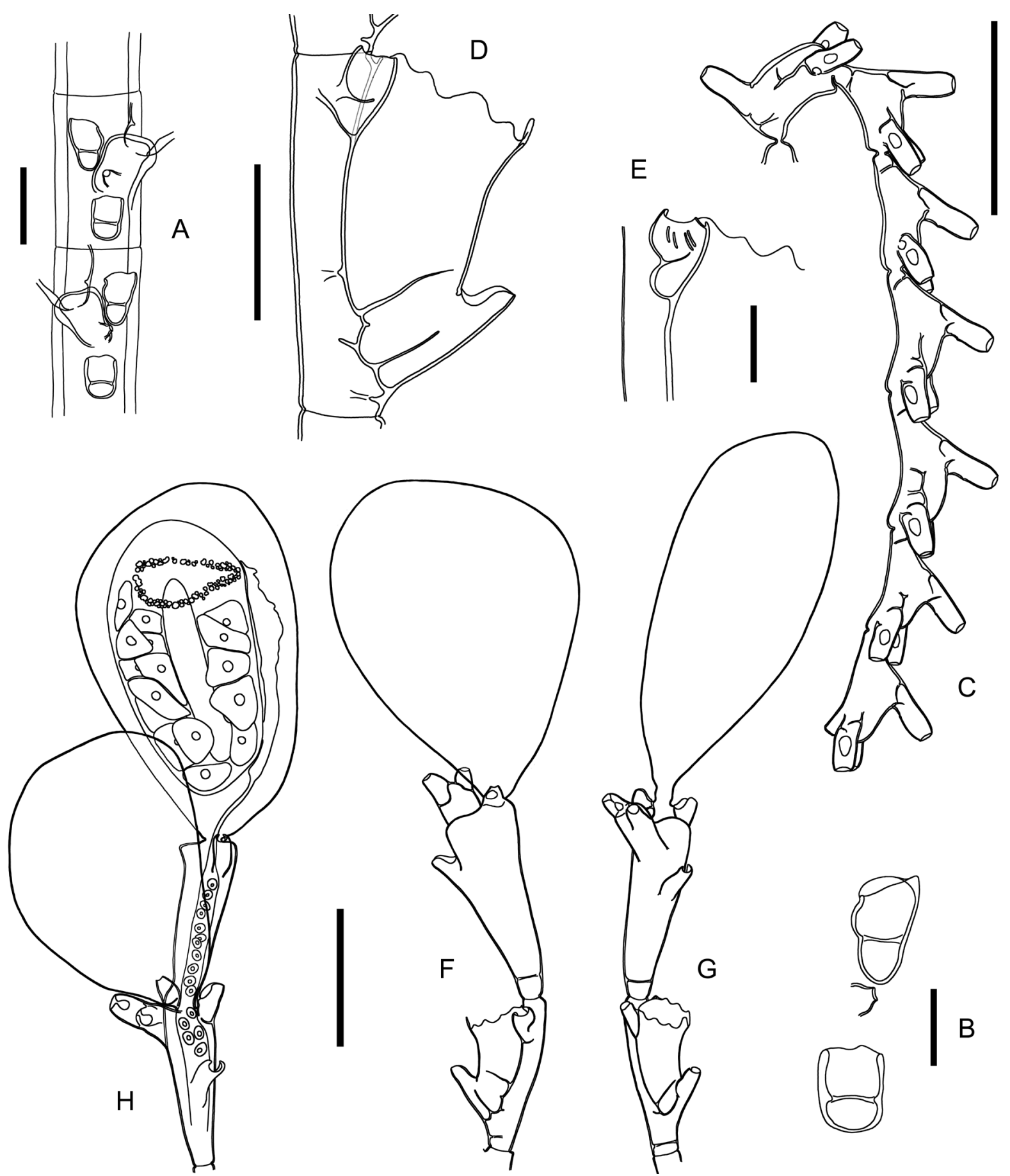

Fig. 19. Macrorhynchia spiralis sp. nov., from sample MNHN-IK-2015-519. A- B. Portion of stem (A) and detail of the nematothecae from the vicinity of a cladial apophysis (B). C. Pseudophylactocarp. D-E. Hydrotheca (D) and one of its lateral nematothecae (E), both in lateral view. F-H. Same phylactocarp with empty gonotheca in two different views $(\mathrm{F}-\mathrm{G})$, and phylactocarp with two gonothecae, one of which bears a female medusoid gonophore $(\mathrm{H})$. Scale bars: $\mathrm{A}, \mathrm{D}=200 \mu \mathrm{m} ; \mathrm{B}, \mathrm{E}=100 \mu \mathrm{m}, \mathrm{C}, \mathrm{F}-\mathrm{H}=$ $500 \mu \mathrm{m}$. 
Table 3. Nominal species of Macrorhynchia Kirchenpauer, 1872 with saccate hydrothecae and adaxial but no abaxial, intrathecal septa, similar to those of Macrorhynchia spiralis sp. nov., and their morphological differences to the new species.

\begin{tabular}{|c|c|}
\hline Nomina & Brief description, with emphasis on the distinctive features, and geographical distribution \\
\hline $\begin{array}{l}\text { allmani } \\
\text { utting, 1900) }\end{array}$ & $\begin{array}{l}\text { Mesial nematotheca adnate for most of its length to the abaxial wall of hydrotheca, distal } \\
\text { tip reaching the hydrothecal aperture. Gonosome described by Galea (2013). Distribution: } \\
\text { tropical western Atlantic (Calder 1997). }\end{array}$ \\
\hline $\begin{array}{l}\text { M. clarkei } \\
\text { (Nutting, 1900) }\end{array}$ & $\begin{array}{l}\text { Mesial nematotheca adnate for most of its length to the abaxial wall of hydrotheca, distal } \\
\text { tip reaching the hydrothecal aperture. Gonosome described by Ansín Agís et al. (2001). } \\
\text { Distribution: tropical western Atlantic, Cape Verde Islands (Calder 2013). }\end{array}$ \\
\hline (Nutting, 1900) & $\begin{array}{l}\text { orly known species, with mesial nematotheca reaching middle part of the abaxial wall of } \\
\text { drotheca. Gonosome unknown. Distribution: Bahamas (Nutting 1900). }\end{array}$ \\
\hline ta & $\begin{array}{l}\text { orly known species, with mesial nematotheca reaching middle part of the abaxial wall of } \\
\text { drotheca. Gonosome unknown. Distribution: Bahamas (Nutting 1900). }\end{array}$ \\
\hline $\begin{array}{l}\text { M. grandis } \\
\text { (Clarke, 1879) }\end{array}$ & $\begin{array}{l}\text { Poorly known species, with mesial nematotheca adnate for most of its length to the abaxial } \\
\text { wall of hydrotheca, distal tip reaching or surpassing the hydrothecal aperture. Gonosome } \\
\text { described by Nutting (1900) Distribution: tropical western Atlantic (Calder 1997). }\end{array}$ \\
\hline $\begin{array}{l}\text { M. hawaiensis } \\
\text { (Nutting, 1905) }\end{array}$ & $\begin{array}{l}\text { Poorly known species, with mesial nematotheca becoming free in middle of hydrotheca, tip } \\
\text { not reaching aperture; one median abaxial cusp and } 2 \text { pairs of } 2 \text { small, uneven lateral cusps. } \\
\text { Gonophore described by Nutting (1905). Distribution: Hawai'i (Nutting 1905). }\end{array}$ \\
\hline iramosa & $\begin{array}{l}\text { Poorly known species, with mesial nematothecae almost as long as the abaxial side of the } \\
\text { hydrotheca, becoming free just below the thecal aperture. Gonosome unknown. Distribution: } \\
\text { Dorsey Canyon, Gulf of Mexico (Fraser 1945). }\end{array}$ \\
\hline M. & $\begin{array}{l}\text { orly known species, with mesial nematotheca adnate for most of its length to the abaxial } \\
\text { ll of hydrotheca, tip almost reaching the rim; first cormidium with asymmetrical lateral } \\
\text { natothecae. Distribution: Florida, USA (Leloup 1937). }\end{array}$ \\
\hline$M$ & $\begin{array}{l}\text { Small hydroid. Hydrotheca constricted above the site where the mesial nematotheca becomes } \\
\text { free; with abaxial carina ending distally in rounded crest; mesial nematotheca partly } \\
\text { adnate to lower abaxial wall of hydrotheca; lateral nematothecae reaching the rim; margin } \\
\text { with } 1 \text { median, abaxial cusp narrow and incurved, as well as } 4 \text { pairs of laterals: } 1^{\text {st }} \text { rounded } \\
\text { triangular, slightly projecting outwards, } 2^{\text {nd }} \text { long, roughly rectangular, strongly incurved over } \\
\text { hydrothecal aperture, } 3^{\text {rd }} \text { broad, rounded at apex and projecting outwards, } 4^{\text {th }} \text { long, narrow, } \\
\text { slightly incurved over hydrothecal aperture (Mulder \& Trebilcock } 1916 \text { ). Gonosome described } \\
\text { by Watson (1973). Distribution: southern Australia (Mulder \& Trebilcock 1916, Watson 1973). }\end{array}$ \\
\hline $\begin{array}{l}\text { M. racemifera } \\
\text { (Allman, 1883) }\end{array}$ & $\begin{array}{l}\text { orly known species, with mesial nematotheca adnate for most of its length to the abaxial } \\
11 \text { of hydrotheca, distal tip overtopping the hydrothecal aperture. Gonosome described in the } \\
\text { ginal account. Distribution: off Bahia, Brazil (Allman 1883). }\end{array}$ \\
\hline $\begin{array}{l}\text { M. ramosa } \\
\text { (Fewkes, 1881) }\end{array}$ & $\begin{array}{l}\text { Poorly known species, with mesial nematotheca adnate for most of its length to the abaxial } \\
\text { wall of hydrotheca, distal tip overtopping the hydrothecal aperture. Distribution: tropical } \\
\text { western Atlantic (Calder 1997). }\end{array}$ \\
\hline 881$)$ & $\begin{array}{l}\text { sial nematotheca adnate for almost the whole length of the } \\
\text { ssome unknown. Distribution: Montserrat (Fewkes 1881). }\end{array}$ \\
\hline $\begin{array}{l}\text { M. similis } \\
\text { (Nutting, } 19\end{array}$ & $\begin{array}{l}\text { Poorly known species, with rather deep hydrothecae, with nearly horizontal aperture; rim } \\
\text { with median, abaxial cusps and } 3 \text { pairs of laterals; mesial nematotheca becoming free in } \\
\text { middle of hydrotheca, laterals tubular and narrow, distinctly overtopping the hydrothecal rim; } \\
\text { phylactocarps with normal cormidium proximally, followed by a few short internodes carrying } \\
\text { abortive (closed) hydrothecae that retain only their normal complement of nematothecae; no } \\
\text { pseudophylactocarps. Distribution: Hawai'i (Nutting 1905). }\end{array}$ \\
\hline
\end{tabular}


septum, of a slightly sigmoid appearance, is given off softly obliquely from the lower part of the adaxial thecal wall, penetrating deep into the lumen, almost reaching the abaxial wall; mesial nematotheca fused to the abaxial wall of hydrotheca for most of its length, leaving distally a short (45-60 $\mu \mathrm{m}$ long), spout-shaped aperture, not reaching the middle of the hydrotheca; lateral nematothecae broadly barrelshaped, 110-120 $\mu \mathrm{m}$ long and ca $50 \mu \mathrm{m}$ wide at aperture, rim scooped out on adaxial side. Fertile colonies produce two distinct structures: one not associated to the gonosome, the other being part of it. The former are pseudophylactocarps, composed of a chain of modified hydrothecae devoid of lumina, but retaining their complement of nematothecae (the latter are all tubular, with a rounded distal aperture and an ovoid, proximal, adaxial one); they are abundantly borne on small, alternate apophyses arising regularly and slightly laterally to the nematothecae of the proximal (acladiate) portion of branches, and encircle their long axis; no gonothecae have been observed associated with the pseudophylactocarps. The gonosome proper is borne on the distal parts of distally-modified cladia that retain proximally 1 (occasionally up to 4) normal cormidia, followed by 1-2 elongated internodes representing atrophied hydrothecae (devoid of lumina) that retain their normal complement of nematothecae, in addition to which a pair of nematothecae (similar to the laterals) is mounted on a conspicuous lateral, subterminal projection. There is some variation in the structure of the proximal part of the fertile cladium: the proximalmost hydrotheca (when only one is present) may be suppressed and replaced by one or two short internodes, the proximalmost bearing one nematotheca, the second three (one mesial and a pair of laterals). Gonothecae lenticular, 1150-1380 $\mu \mathrm{m}$ long and 750-795 $\mu \mathrm{m}$ wide, with flimsy perisarc, inserted between the pair of lateral nematothecae of the distalmost, atrophied hydrotheca; the gonophore is a medusoid, composed of a central spadix encircled by a single layer of large oocytes (the holotype is a female colony), and bearing apically a belt of refringent corpuscles.

\section{Remarks}

Hydrothecae with similar shape as those of M. spiralis sp. nov., i.e., cup-shaped, with intrathecal adaxial but not abaxial ridge, are found in a number of congeners. Their distinguishing features with respect to the new species are emphasized in Table 3.

As noted above, this species produces a medusoid gonophore. At least three other nominal species reproduce in a similar way, namely M. filamentosa (De Lamarck, 1816), M. philippina Kirchenpauer, 1872 and M. racemifera (Allman, 1883) (Galea 2018), suggesting that this mode of dispersal could be the rule within the genus, as it probably is in the plumulariid genus Dentitheca Stechow, 1920 (Galea et al. 2012).

\section{Distribution}

Known only from off New Caledonia (present study).

\section{Discussion}

No account published so far dealt expressly with the aglaopheniid hydroids of New Caledonia. However, other families have been studied quite accurately (e.g., Sertularellidae Maronna et al., 2016, Sertulariidae Lamouroux, 1812, Lafoeidae Hincks, 1868, Halopterididae Millard, 1962, Kirchenpaueriidae Stechow, 1921 and Plumulariidae McCrady, 1859), while some others have received lesser attention due to a limited number of collected specimens (e.g., Staurothecidae Maronna et al., 2016, Symplectoscyphidae Maronna et al., 2016, Syntheciidae Marktanner-Turneretscher, 1890, Thyroscyphidae Stechow, 1920 and Zygophylacidae Quelch, 1885) (all reviewed and/or dealt with in Galea (2016) and Galea \& Schuchert (2019)). The aglaopheniid hydroids belong to the latter category, with only 16 species occurring in collections from the KANACONO and KANADEEP expeditions. Of these, eight hydroids represent new species: three belong to the genus Cladocarpus Allman, 1874, four to Lytocarpia Kirchenpauer, 1872 and one to Macrorhynchia Kirchenpauer, 1872, thus advancing our knowledge on the hydroid fauna of the region. 


\section{Acknowledgements}

Specimens were obtained during expeditions organized by the MNHN and Pro-Natura International as part of the "Our Planet Reviewed" program, and by the MNHN and the "Institut de Recherche pour le Développement" as part of the "Tropical Deep-Sea Benthos Program". The collectors are grateful to the crew of R/V Alis and to the cruise leaders Nicolas Puillandre (KANACONO), Sarah Samadi and Stephane Houdez (KANADEEP). All expeditions were operated under the regulations in force and satisfy the conditions set by the Nagoya Protocol for the access to genetic resources. Sincere thanks go to two anonymous referees for their thorough review of the manuscript and their helpful comments.

\section{References}

Allman G.J. 1877. Report on the Hydroida collected during the exploration of the Gulf Stream by L. F. de Pourtalès, Assistant United States Coast Survey. Memoirs of the Museum of Comparative Zoölogy at Harvard College 5 (2): 1-66. https://doi.org/10.5962/bhl.title.10420

Allman G.J. 1883. Report on the Hydroida dredged by H.M.S. Challenger during the years 1873-76. Part I. - Plumularidae. Report on the Scientific Results of the Voyage of H.M.S. Challenger during the Years 1873-76, Zoology 7 (20): 1-55. https://doi.org/10.5962/bhl.title.11299

AltunaA., Murillo F.J. \& Calder D.R. 2013. Aglaopheniid hydroids (Cnidaria: Hydrozoa: Aglaopheniidae) from bathyal waters of the Flemish Cap, Flemish Pass, and Grand Banks of Newfoundland (NW Atlantic). Zootaxa 3757 (5): 501-537. https://doi.org/10.11646/zootaxa.3737.5.1

Ansín Agís J., Ramil F. \& Vervoort W. 2001. Atlantic Leptolida (Hydrozoa, Cnidaria) of the families Aglaopheniidae, Halopterididae, Kirchenpaueriidae and Plumulariidae collected during the CANCAP and Mauritania-II expeditions of the National Museum of Natural History, Leiden, the Netherlands. Zoologische Verhandelingen, Leiden 333: 1-268.

Available from https://repository.naturalis.nl/document/46286 [accessed 6 Mar. 2020].

Bale W.M. 1888. On some new and rare Hydroida in the Australian Museum collection. Proceedings of the Linnean Society of New South Wales 2 (3) 2: 745-799. https://doi.org/10.5962/bhl.title.26267

Bale W.M. 1914. Report on the Hydroida collected in the Great Australian Bright and other localities, II. Fisheries. Zoological (and Biological) Results of the Fishing Experiments carried out by F.I.S. "Endeavour", 1909-1910 2(4): 164-188.

Bale W.M. 1919. Further notes on Australian hydroids. IV. Proceedings of the Royal Society of Victoria 31 (2): 327-362.

Bedot M. 1921. Hydroïdes provenant des campagnes des Yachts Hirondelle et Princesse-Alice (18871912). Résultats des Campagnes scientifiques accomplies sur son Yacht par Albert I ${ }^{\text {er }}$ Prince souverain de Monaco 60: 1-74.

Billard A. 1913. Les hydroïdes de l'expédition du Siboga. I. Plumulariidae. Siboga-Expeditie Monographie 7a: 1-115.

Billard A. 1918. Notes sur quelques espèces d'hydroïdes de l'Expédition du Siboga. Archives de Zoologie expérimentale et générale 57: 21-27.

Billard A. 1934. Note sur quelques hydroïdes du Maroc. Bulletin de la Société zoologique de France 59: 227-231.

Bogle M.A. 1975. A Review and Preliminary Revision of the Aglaopheniinae (Hydroida: Plumulariidae) of the Tropical Western Atlantic. MSc Thesis, University of Miami, Coral Gables, USA. 
Bogle M.A. 1984. Cladocarpoides yucatanicus, a new genus and species of Aglaopheniinae (Coelenterata: Hydroida: Plumulariidae) from Arrowsmith Bank, Yucatan Channel. Bulletin of Marine Science 34 (1): 135-140.

Briggs E.A. 1918. Descriptions of two new hydroids, and a revision of the hydroid-fauna of Lord Howe Island. Records of the Australian Museum 12 (3):27-47.https://doi.org/10.3853/j.0067-1975.12.1918.878

Broch H. 1918. Hydroida (Part II). Danish Ingolf-Expedition 5 (7): 1-206.

Calder D.R. 1997. Shallow-water hydroids of Bermuda: superfamily Plumularioidea. Royal Ontario Museum Life Sciences Contributions 161: 1-84.

Calder D.R. 2013. Some shallow-water hydroids (Cnidaria: Hydrozoa) from the central east coast of Florida, USA. Zootaxa 3648 (1): 1-72. https://doi.org/10.11646/zootaxa.3648.1.1

Calder D.R. \& Vervoort W. 1998. Some hydroids (Cnidaria: Hydrozoa) from the Mid-Atlantic Ridge, in the North Atlantic Ocean. Zoologische Verhandelingen, Leiden 319: 1-65.

Available from https://www.repository.naturalis.nl/document/149104 [accessed 6 Mar. 2020].

Cornelius P.F.S. 1995. North-west European thecate hydroids and their medusae. Part 2. Sertulariidae to Campanulariidae. Synopses of the British Fauna 50: 1-386.

Di Camillo C.G., Puce S. \& Bavestrello G. 2009. Macrorhynchia species (Cnidaria: Hydrozoa) from the Bunaken Marine Park (North Sulawesi, Indonesia) with a description of two new species. Italian Journal of Zoology 76 (2): 208-228. https://doi.org/10.1080/11250000802182018

Di Camillo C.G., Puce S. \& Bavestrello G. 2011. Lytocarpia and Cladocarpus (Cnidaria: Hydrozoa, Aglaopheniidae) from the Bunaken National Marine Park (North Sulawesi, Indonesia). Marine Biology 41 (4): 517-536. https://doi.org/10.1007/s12526-011-0081-4

Fewkes J.W. 1881. Report on the Acalephae. In: Reports on the results of dredging, under the supervision of Alexander Agassiz, in the Caribbean Sea, in 1878, 1879, and along the Atlantic coast of the United States, during the summer of 1880, by the U.S. Coast Survey Steamer Blake. Bulletin of the Museum of Comparative Zoölogy, at Harvard College 8 (7): 127-140.

Available from https://www.biodiversitylibrary.org/page/28870347 [accessed 6 Mar. 2020].

Fraser C.M. 1945. Notes on some recently collected hydroids in the United States National Museum, with descriptions of three new species. Journal of the Washington Academy of Sciences 35 (1): 21-23.

Galea H.R. 2007. Hydroids and hydromedusae (Cnidaria: Hydrozoa) from the fjords region of southern Chile. Zootaxa 1597: 1-116.

Galea H.R. 2008. On a collection of shallow-water hydroids (Cnidaria: Hydrozoa) from Guadeloupe and Les Saintes, French Lesser Antilles. Zootaxa 1878: 1-54.

Galea H. R. 2013. New additions to the shallow-water hydroids (Cnidaria: Hydrozoa) from the French Lesser Antilles: Martinique. Zootaxa 3686 (1): 1-50. https://doi.org/10.11646/zootaxa.3686.1.1

Galea H.R. 2016. Notes on some sertulariid hydroids (Cnidaria: Hydrozoa) from the tropical western Pacific, with descriptions of nine new species. European Journal of Taxonomy 218: 1-52.

https://doi.org/10.5852/ejt.2016.218

Galea H.R. 2018. A swimming medusoid gonophore in the life cycle of Ventromma halecioides (Alder, 1859) (Hydrozoa: Leptothecata: Kirchenpaueriidae). Revue suisse de Zoologie 125 (1): 137-147. https://doi.org/10.5281/zenodo.1196038

Galea H.R. \& Schuchert P. 2019. Some thecate hydroids (Cnidaria: Hydrozoa) from off New Caledonia collected during KANACONO and KANADEEP expeditions of the French Tropical Deep-Sea Benthos Program. European Journal of Taxonomy 562: 1-70. https://doi.org/10.5852/ejt.2019.562 
Galea H.R., Ferry R. \& Bertot J.M. 2012. Medusoids in the life cycle of Dentitheca dendritica (Nutting, 1900) and Nemalecium gracile sp. nov. (Cnidaria: Hydrozoa). Zootaxa 3527: 43-54.

https://doi.org/10.11646/zootaxa.3527.1.3

Hirohito, Emperor of Japan. 1983. Hydroids from Izu Ôshima and Niijima. Publications of the Biological Laboratory, Imperial Household, Tokyo.

Hirohito, Emperor of Japan. 1995. The hydroids of Sagami Bay. II. Thecata. Publications of the Biological Laboratory, Imperial Household, Tokyo.

Inaba M. 1891. Hydroids obtained at Misaki, Miura, Sôshû. Dobutsugaku Zasshi (Zoological Magazine, Tokyo) 3 (34): 301-309.

Jäderholm E. 1903. Aussereuropäische Hydroiden im schwedischen Reichsmuseum. Arkiv för Zoologi 1: 259-312.

Jäderholm E. 1917. Hydroids from the South Seas. Redogörelse för Norrköpings Högre Allmänna Lävoverk Läsaret 1916-1917: 1-25.

Kramp P.L. 1935. Polypdyr (Coelenterata). I. Ferskvardspolypper og Goplepolypper. Danmarks Fauna 41: 1-207.

Leloup E. 1937. Hydropolypes et Scyphopolypes recueillis par C. Dawydoff sur les côtes de l'Indochine française. Mémoires du Musée royal d'Histoire naturelle de Belgique 2 (12): 1-73.

Migotto A.E. 1996. Benthic shallow-water hydroids (Cnidaria, Hydrozoa) of the coast of São Sebastião, Brazil, including a checklist of Brazilian hydroids. Zoologische Verhandelingen, Leiden 306: 1-125. Available from https://www.repository.naturalis.nl/document/148871 [accessed 6 Mar. 2020].

Millard N.A.H. 1975. Monograph on the Hydroida of southern Africa. Annals of the South African Museum 68: 1-513.

Mulder J.F. \& Trebilcock R.E. 1916. Notes on Victorian Hydroida. Part VI. Geelong Naturalist 6 (4): $73-84$.

Nutting C.C. 1900. American hydroids. Part I. The Plumularidae. Special Bulletin of the United States National Museum 4 (1): 1-285. https://doi.org/10.5962/bhl.title.1327

Nutting C.C. 1905. Hydroids of the Hawaiian islands collected by the Steamer Albatross in 1902. Bulletin of the United States Fish Commission 23 (3): 931-959.

Park J.H. 2010. Invertebrate fauna of Korea. Cnidaria: Hydrozoa: Thecatae. Thecates. Flora and Fauna of Korea 4 (1): 1-183.

Ralph P.M. 1961. New Zealand thecate hydroids. Part III. Family Sertulariidae. Transactions of the Royal Society of New Zealand 88 (4): 749-838.

Ramil F. \& Vervoort W. 1992a. Some consideration concerning the genus Cladocarpus (Cnidaria: Hydrozoa). Scientia Marina 56 (2-3): 171-176.

Available from http://scimar.icm.csic.es/scimar/pdf/56/sm56n2171.pdf [accessed 6 Mar. 2020].

Ramil F. \& Vervoort W. 1992b. Report on the Hydroida collected by the "BALGIM" expedition in and around the Strait of Gibraltar. Zoologische Verhandelingen, Leiden 277: 1-262.

Available from https://www.repository.naturalis.nl/document/149146 [accessed 6 Mar. 2020].

Ramil F., Vervoort W. \& Ansín Agís J. 1998. Report on the Haleciidae and Plumularioidea (Cnidaria, Hydrozoa) collected by the French Seamount 1 Expedition. Zoologische Verhandelingen, Leiden 322: 1-42. Available from https://www.repository.naturalis.nl/document/149163 [accessed 6 Mar. 2020]. 
Rees W.J. \& Vervoort W. 1987. Hydroids from the John Murray expedition to the Indian Ocean, with revisory notes on Hydrodendron, Abietinella, Cryptolaria and Zygophylax (Cnidaria: Hydrozoa). Zoologische Verhandelingen, Leiden 237: 1-209.

Available from https://www.repository.naturalis.nl/document/148867 [accessed 6 Mar. 2020].

Rho B.J. 1967. Marine hydroids from the West and the South Sea of Korea. Korean Cultural Research Institute, Ehwa Womans University 10: 341-360.

Rho B.J. \& Park J.H. 1980. A systematic study on the marine hydroids in Korea 6. Thecata. Journal of Korean Research Institute for Better Living 25: 15-43.

Ronowicz M., Boissin E., Postaire B., Bourmaud C. A.-F., Gravier-Bonnet N. \& Schuchert P. 2017. Modern alongside traditional taxonomy - Integrative systematics of the genera Gymnangium Hincks, 1874 and Taxella Allman, 1874 (Hydrozoa, Aglaopheniidae). PLOS ONE 12 (4): 1-43. https://doi.org/10.1371/journal.pone.0174244

Ryland J.S. \& Gibbons M.J. 1991. Intertidal and shallow water hydroids from Fiji. II. Plumulariidae and Aglaopheniidae. Memoirs of the Queensland Museum 30 (3): 525-560.

Sars G.O. 1874. Bidrag til Kundskaben om Norges Hydroider. Forhandlinger $i$ Videnskabs-Selskabet $i$ Kristiania 1873: 91-150.

Schuchert P. 2001. Hydroids of Greenland and Iceland. Meddelelser om Grønland, Bioscience 53: $1-184$.

Schuchert P. 2003. Hydroids (Cnidaria, Hydrozoa) of the Danish expedition to the Kei Islands. Steenstrupia 27 (2): 137-256.

Schuchert P. 2015. On some hydroids (Cnidaria, Hydrozoa) from the Okinawa Islands, Japan. Revue suisse de Zoologie 122 (2): 325-370. https://doi.org/10.5281/zenodo.30004

Schuchert P. 2019. World Hydrozoa Database. Lytocarpia Kirchenpauer, 1872.

Available from http://www.marinespecies.org/hydrozoa/aphia.php? $\mathrm{p}=$ taxdetails\&id=117002 [accessed 8 Oct. 2019].

Stechow E. 1913. Hydroidpolypen der japanischen Ostküste. II. Teil: Campanularidae, Halecidae, Lafoeidae, Campanulinidae und Sertularidae, nebst Ergänzungen zu den Athecata und Plumularidae. In: Doflein F. (ed.) Beiträge zur Naturgeschichte Ostasiens. Abhandlungen der Königlich Bayerischen Akademie der Wissenschaften, Supplementband zu den Abhandlungen der Mathematischnaturwissenschaftlichen Klasse 3 (2): 1-162. https://doi.org/10.5962/bhl.title.11621

Stechow E. 1921. Über Hydroiden der Deutschen Tiefsee-Expedition, nebst Bemerkungen über einige andre Formen. Zoologischer Anzeiger 53: 223-236.

Thornely L.R. 1904. Report on the Hydroida collected by Professor Herdman, at Ceylon, in 1902. Ceylon Pearl Oyster Fisheries, Supplemental Report 8: 107-126.

Totton A.K. 1930. Coelenterata. Part V. Hydroida. Natural History Report of the British Antarctic ("Terra Nova") Expedition, 1910. Zoology 5 (5): 131-252.

Vervoort W. 1941. The Hydroida of the Snellius Expedition (Milleporidae and Stylasteridae excluded). Temminckia 6: 186-240.

Vervoort W. 1966. Bathyal and abyssal hydroids. Scientific Results of the Danish Deep-Sea Expedition 1950-1952. Galathea Report 8: 97-174.

Vervoort W. 1972. Hydroids from the Theta, Vema and Yelcho cruises of the Lamont-Doherty Gological Observatory. Zoologische Verhandelingen, Leiden 120: 1-247.

Available from https://www.repository.naturalis.nl/document/149147 [accessed 6 Mar. 2020]. 
Vervoort W. \& Watson J.E. 2003. The marine fauna of New Zealand: Leptothecata (Cnidaria: Hydrozoa) (thecate hydroids). NIWA Biodiversity Memoir 119: 1-538.

Available from https://archive.org/details/niwabiodiversitymemoir01192003 [accessed 6 Mar. 2020].

Watson J.E. 1973. Pearson Island Expedition 1969. - 9. Hydroids. Transactions of the Royal Society of South Australia 97 (3): 153-200.

Watson J.E. 1994. Shallow water hydroids from eastern Bass Strait. Victoria Naturalist 111 (2): 65-70.

Watson J.E. 2000. Hydroids (Hydrozoa: Leptothecata) from the Beagle Gulf and Darwin Harbour, northern Australia. The Beagle, Records of the Museum and Art Galleries of the Northern Territory 16: 1-82. Available from https://www.biodiversitylibrary.org/page/55260920\#page/5/mode/1up [accessed 6 Mar. 2020].

Watson J.E. 2002. Hydroids (Cnidaria: Hydrozoa) from southern Queensland. Memoirs of the Museum of Victoria 59 (2): 337-354. https://doi.org/10.24199/j.mmv.2002.59.6

Watson J.E. 2018. Some hydroids (Cnidaria, Hydrozoa) from the Great Australian Bight in the collection of the South Australian Museum. Zootaxa 4410 (1): 1-34. https://doi.org/10.11646/zootaxa.4410.1.1

Whitelegge T. 1899a. Hydrozoa. In: Etheridge, Jr. R. (ed.) The General Zoology of Lord Howe Islands; Containing also an Account of the Collections Made by the Australian Museum Collecting Party, Aug.Sep. 1887. Memoirs of the Australian Museum 2: 41.

Whitelegge T. 1899b. List of the marine and fresh-water invertebrate fauna of Port Jackson. Proceedings of the Royal Society of New South Wales 23: 163-323.

Xu Z.Z., Huang J.Q., Lin M., Guo D.H. \& Wang C.G. 2014. Study of Marine Biodiversity. The Superclass Hydrozoa of the Phylum Cnidaria in China. Vol. II. China Ocean Press, Beijing.

Manuscript received: 9 October 2019

Manuscript accepted: 10 December 2019

Published on: 13 March 2020

Topic editor: Rudy Jocqué

Desk editor: Kristiaan Hoedemakers

Printed versions of all papers are also deposited in the libraries of the institutes that are members of the EJT consortium: Muséum national d'histoire naturelle, Paris, France; Meise Botanic Garden, Belgium; Royal Museum for Central Africa, Tervuren, Belgium; Royal Belgian Institute of Natural Sciences, Brussels, Belgium; Natural History Museum of Denmark, Copenhagen, Denmark; Naturalis Biodiversity Center, Leiden, the Netherlands; Museo Nacional de Ciencias Naturales-CSIC, Madrid, Spain; Real Jardín Botánico de Madrid CSIC, Spain; Zoological Research Museum Alexander Koenig, Bonn, Germany; National Museum, Prague, Czech Republic. 